$$
\begin{aligned}
& \text { S B } \\
& 355 \\
& N_{5}
\end{aligned}
$$




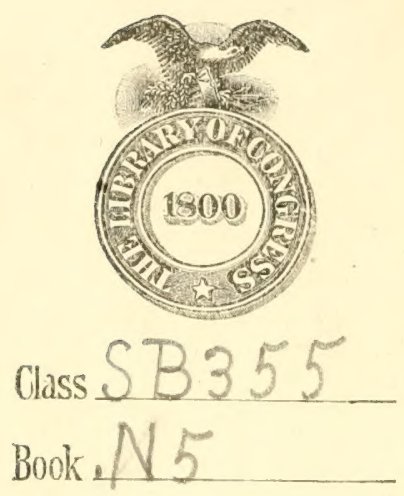

Copyright No

COPYRIGHT DEPOST. 


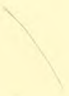






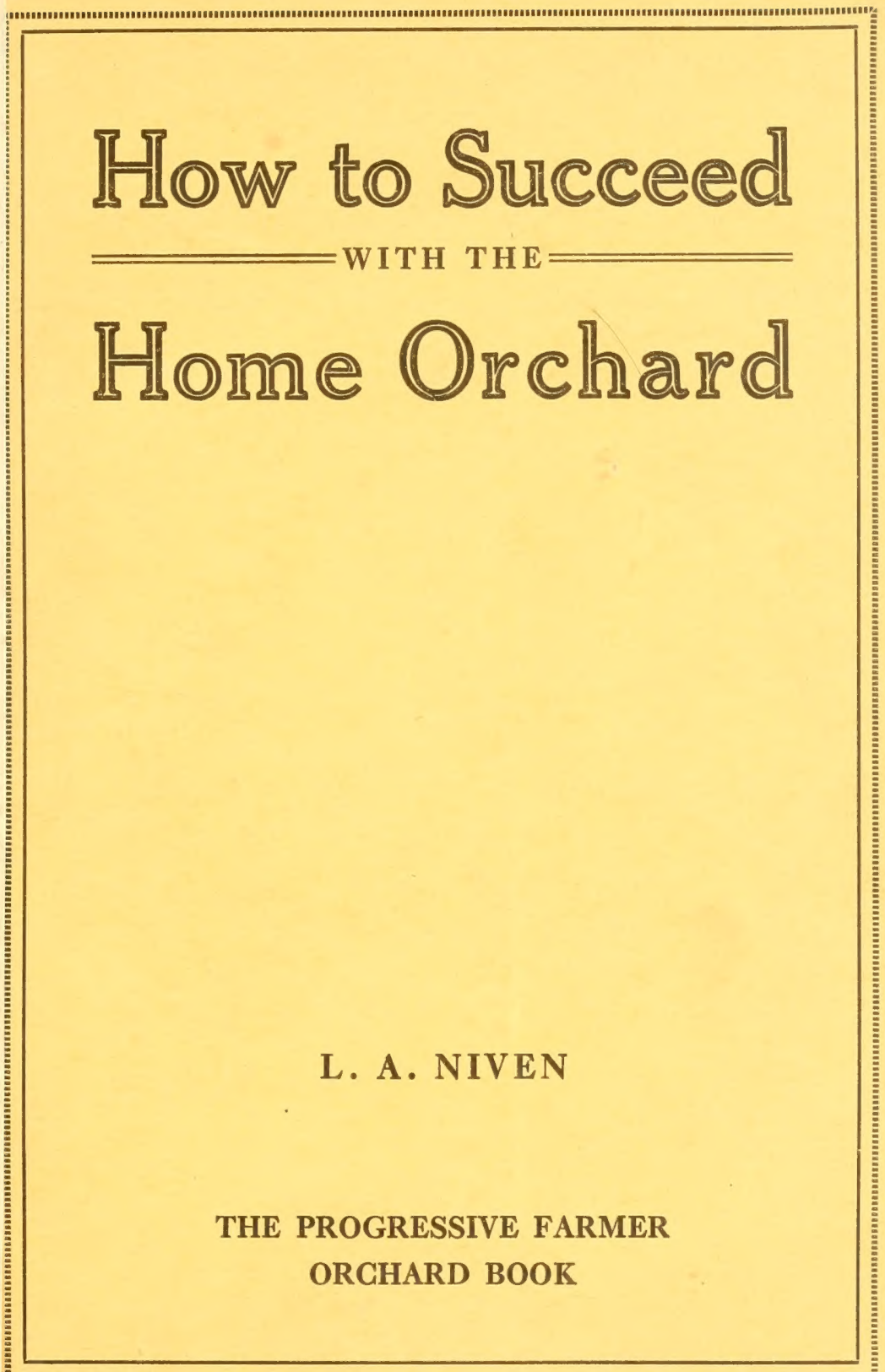





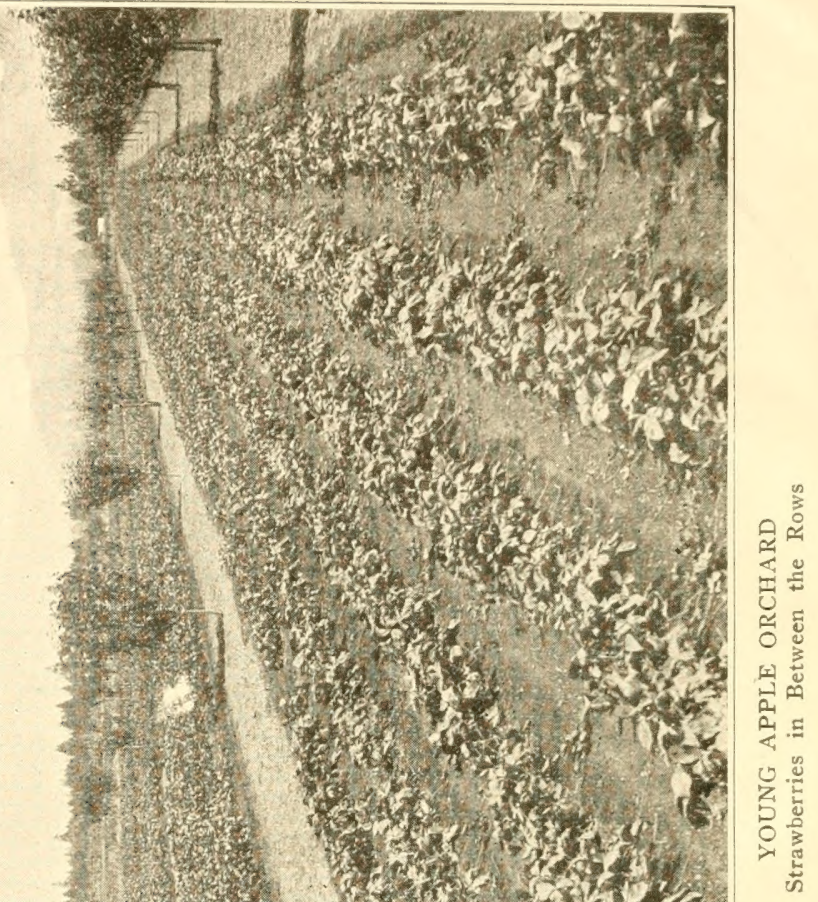




\section{How To Succeed}

W I T H

The Home Orchard

By

L. A. NIVEN, B. Agr.

Advertising Manager

THE PROGRESSIVE FARMER

THE PROGRESSIVE FARMER COMPANY PUBLIS HERS

\begin{tabular}{lr}
\hline \hline $\begin{array}{l}\text { Raleigh } \\
\text { Atlanta }\end{array}$ & Birmingham \\
\hline
\end{tabular}




\section{$5 \frac{5}{25}$}

Copyright, I920,

$B y$

The Progressive Farmer Company

DEC 171920

(C) C. $A 606447$ 


\section{CONTENTS}

Chapter I. Plan of the Orchard.

Chapter II. The Site or Location of the Orchard.

Chapter III. When, Where and How to Buy Fruit Trees.

Chapter IV. Description of Some Leading Varieties of Apples and Peaches.

Chapter V. Treatment of Trees When Received From Nursery.

Chapter VI. Setting Fruit Trees.

Chapter VII. Heading Back Fruit Trees at Time of Setting.

Chapter VIII Cultivating the Orchard.

Chapter IX. Fertilizing liruit T'rees.

Chapter X. Pecan Growing in the South.

Chapter XI. Figs Grow Well in Cotton Belt.

Chapter XII. Pruning Fruit Trees.

Chapter XIII. Grading and Displaying Fruits.

Chapter XIV. Varieties of Fruit That Should Succeed in the South.

Chapter XV. Tools Needed to Do First Class Pruning.

Chapter XVI. Winter Spraying of Fruit Trees.

Clapter XVII. Spring and Summer Sprays for Different Fruits.

Chapter XVIII. How to Make the Summer Spray Mixtures.

Chapter XIX. Storing Apples for Winter. 


\section{PREFACE}

This little book is intended to cover the ABC's of orchard work. It is not a complete, technical discussion of iruit-growing, but has for its purpose the giving of helpful hints and plain directions to those who wish to succeed with the home orchard.

It is a well known fact that the home orchard-and a good one at that-should be on every southern farm. We know that this is not now the case. In fact, not one farm in ten las an up-to-date home orchard. Many people put ont iruit trees and let them "knock" for themselves, and the result is clisappointment. By following the simple suggestions given in this little bonk, anyone, it matters not how inexperienced the may be in fruit growing. can love a good home orchard.

We wish to make it clear that we have attempted in this book to discuss this proposition solely from the standpoint of the farmer who is interested in frut-growing only to the extent of having a home orchard to supply the hume with all the fresh fruits needed, and who, from tinne to time, marliets the surplus fruit in the fresh form in nearly towns, either ly taking it directly there in a truck, wagon or buggy, or by shipping it by express..

The Home Orchard Brings Many Benefits.-We wish right here and now to make a plea for the home orchard. No home or farm, where there is avalable space for a lome orchard, is anything like complete without one. It has been proven again and again that those who consume a liferal supply of fruits and vegetables have far less sicknesin than those who connmue few, if any, fruits and vegetables, but eat heavily of meats.

And then it is the absolute right of every person living on a farm-both old and young (especially the young) to have an abundance of fruits. The farm buy or girl who cannot get plenty of peaches, apples, plums, grapes, ete., is denied a needed pleasure. All of these can be grown so casty and with such little expense that it is an injustice to the farm family not to grow them.

After reading this little luok any persm of ordinary intelligence can succed with a home orchard if he will just follow the instruc tions given. If you are one of those whe has leen doing without fruit. make up your mind right now not to continne in this class.

December, 1920. 


\section{CHAPTER I.}

\section{PLAN OF THE ORCHARD.}

The very first thing to do after deciding to set cont an orchard is to make a careful plan of same. This should be done before it is even decided just where the orchard is to he located. First decide how muth wronnd is to be given to the orchard: then decide how many trees of the different kinds of fruts are to be set; then figntre the distance apart, between the rows and between the indit trees in the rows. for the different kinds of fruits.

Make a Drawing of the Orctard. - It need not be drawn to scale, but can be drawn so as to serve the purpose satisfactorily merely by the use of a pencil and rule.

D raw at square block in the midcle of the sheet of paper, making a douthle line - or a very lieary line-indicating the onter edges and the ends of the orchard. Then draw at line in the direction the rows are to run, making it a thin narrow line, with either pencil or pen and ink.

Then on these lines draw a circle indicating the place where each fruit tree is to be set. () f conrse. before drawing these circles fon must decide just how many row's of the different kinds of fruits you are going to have, and decide the distance apart, so as to place the circle in the right place.

\section{How to Distinguish Varieties.}

Such a plan as this can be (liawn w1) very quickly, and by writing under each circle the name of the variety of each fruit it will be easy to determine just what variety each tree is, and this kinowledge may prove very desirable at some time in the future. Those who are not experts in the matter cannut always tell the variety of peaches, apples. etc., by the fruit itself, and by referring to this little mapplan will enable one to tell what variety any particular tree is. 
8 How to Succeed With the Home Orchard

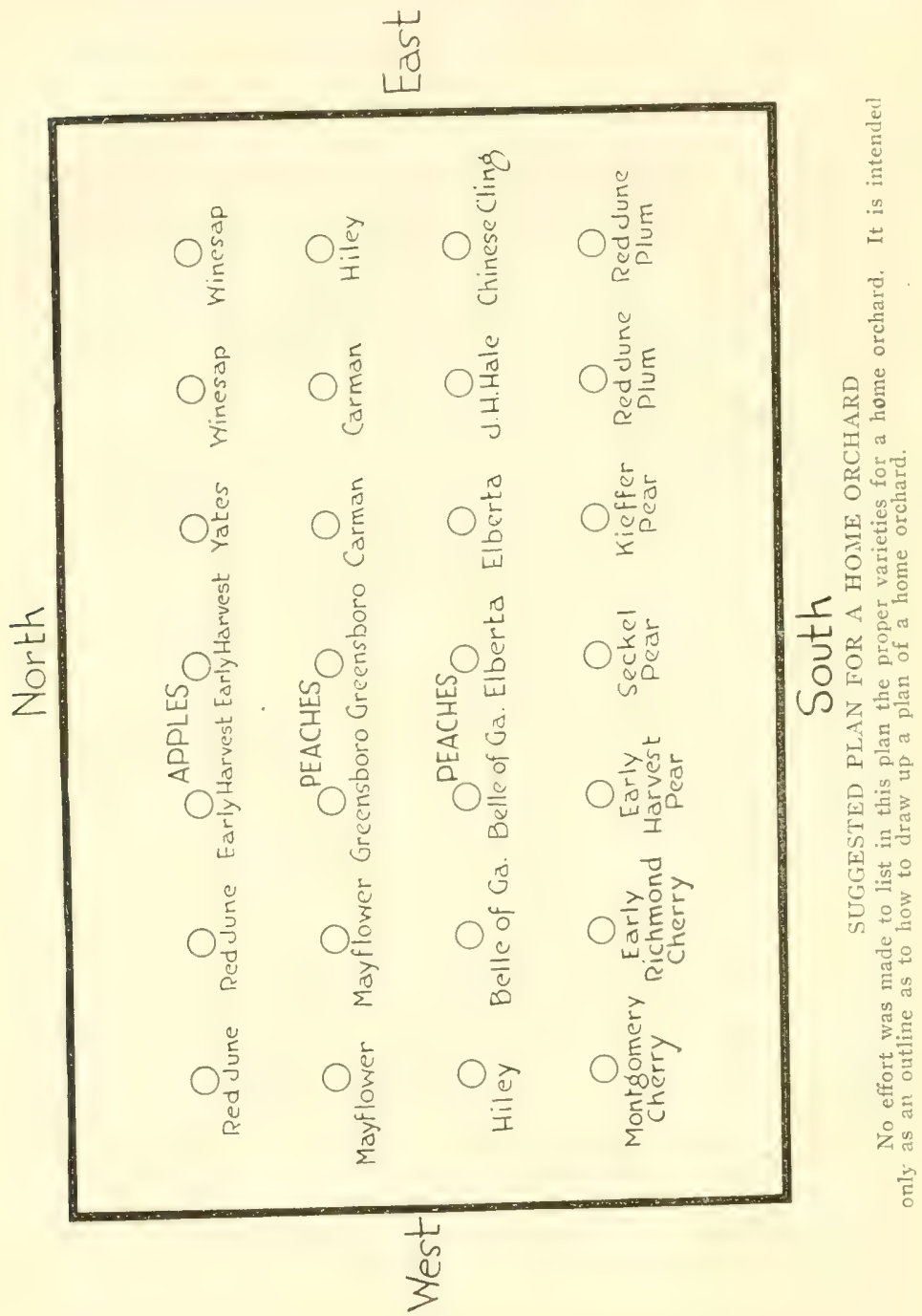


Draw Up Plan. () f contse, each sicle of the orcharel plate shomld he labeled acerrding to direction, that is, east, west, north or south.

Some may deem this needless work, but we have had enomele experience in the setting of small home orchards to know that this is not omly not a needless piece of work, but

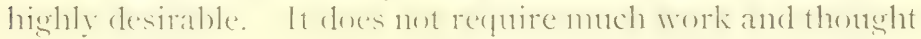
to (lraw up such a plan and to property label it. Therefore. we rarnestly recommend that crervone setting a home orchard draw up one of these plans. 


\section{CHAP'TER II.}

\section{THE SHTEOR LOC ATHON OF THE ORCHARD.}

The site or location of the orchard is extremely inportant. Careful thought should be given to this phase of the matter before the fruit trees are even ordered. Study every available piece of ground on your farm and decide which is the best place, all conclitions being considered.

Give Careful Consideration to the Fertility of the Soil.-One thing that we should like to emphasize: Don't pick out a poor piece of sround for the home orchard. In the cotton belt we believe one of the best methods of determining how rich a piece of ground should be selected for the orchard is to say that the orchard shall be put on a piece of ground that will produce not less than a bale of cotton per acre when properly fertilized and well cultivated. In that part of the South above the cotton belt we believe a piece of ground that will produce at least 35 to 40 bushels of corn per acre shomld be selected. This, of course, is looking at it from the standpoint of soil fertility alone. But we want to emphasize this particular point, because fruit trees are plants just the same as corn or cotton, and to de the best they must be planted on soil that is reasonably fertile.

Of course, the home orchard should be as near the house as possible. Still, it should not be put right near, unless the right kind of soil can be found there.

\section{Ground Must Be Well Drained.}

Select Site With Natural Drainage--The ground where the orchard is to be set must be well drained. It is a well known fact that peach trees comnot stand "wet feet," and apple trees and all other kinds of fruit trees are not nuch different in this respect. Therefore, after picking out a piece of ground that is rich ennugh, we must consider 
whether or not it is well drained, and if it is not well drained, drainage numst be provided if we would staceed with the orchard.

Drainage of Air Is Also Important.- Not only must the piece of ground selected be well drained as far as draining of water is concerned, but the air-dranage must be good. It is a well known fact that cold air is heavier than warm air, and therefore the cold air nettles to the lowest places. This is why one very often sees early spring frost in the branch bottoms and other low places while no frost appears up on the edge or top of the hill.

When to Plant on Level Ground.-Uf course, in any section where the land is all level and there are no high places, then, of necesity one nunst plant the fruit trees on level ground. Then this is the case the proper thing to do is to carefully select the best location with reference to soil drainage and air dranisese : becalse it is an inexorable law that cold air is heavier than warm air and nunst settle to the lowest places. Therefore on cold nights the cold air will invariably be found in the lower spots and the warmer air on the higher places. If these points are kept in mind in selecting the location for the home orchard, there is little doubt but that the arerase person can seleet the best place on the farm for the orchard.

The planting of trees in such low places may very well mean the difference hetween a crop of fruit and no fruit at all. Therefore, it is highly inportant that in selecting the site or location, one should give serions consideration to this phase of the matter. II should not fout the fruit trees down in a low place, even though that low place may be fairly well drained as far as the draining off of the water is concerned. It nuy he accepted as a fact that the lowest places are not well drained as far as air drainage is concerned, and the setting of an orchard in such a place is inviting the loss of a number of crops of fruit that would not be lost if the trees were planted on a hill. 
Plant Trees on Hisin Ground. Froml this discussion it can very well he seen that selelom if erey shomlel one plant iruit trees anywhe other than on a hish spot of exroumd. provider one is not in at section that is all level. Lsually the house and harn are on the highest speste, and this will naturally throw the orchard right near the honse. However, in many instances the lowse and harns are on low spots on the farm, and in such cases by all means put the orchard a good distance away from the honse if this is necessaty in order to get it on a high spot.

Select Soil That Roots Can Penetrate Easily. - IIhile the fertility of the soil and the drainage, with reference te both water and air, are rery inportant points, it is also important to consider the type of snil. ( )n many pieces of around we find the hard pan so very hard as to make it almost impossible for the gommg fruit treses to force their roots through it. Then, in other places we find solid rock within a foot or two of the surface of the ground. Of course, fruit trees should not he planted in such places ats

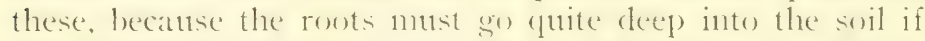
the trees are to grow and flowrish for years to come. Therefore, one should sat isfy himself at least that the place where the orchard is to be planted is not underlaid with solid rocti as near as two or three feet of the surface of the soil.

\section{Clay Subsoil Desirable.}

Best Soil For Fruit Trees.... - wil wh a clay subsoil is very desirable, but this should be at least a foot or more

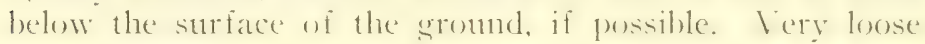
soil, either sandy or wravelly, is not so desirable as the more or less compact soll with a clay subsoil. Iy this we do not mean that a hard soil is desirable, nor do we nean to say that a sandy soil or gratvelly soil will not do fairly well ; but we do neat that a soil which is compact and which has a clay subsoil is usually the nust satisfactory. The subsoil should not be two harel, lout open and porous enough to allow water to soak throwgh and to allow the roots to pene- 
trate the soil without any undue effort. ()ne who has had experience in farming will be able to pick out the kind of soil that will be best by following these sugerestions.

Location of Utmost Importance. - II ('mplatize the absolute necessity of carefully considering the location of the orchard, because one little mistake with reference to this matter will often mean the difference between a good home orchard and one that is no good at all. We have linown many folls to set their home orchards in low places and the result would be magnificent trees-large, beantiful and handsome, but with a small anount of fruit, if any. Therefore, we repeat, put the home orchard on a high piece of ground, preferably near the house, but if it can't be had near the house, then some distance away. 
WHEN, WHERE AND HOW TO BUY FRUIT TREES.

Buy Trees From Reliable Nurseries Only.-The buying of fruit trees is of the utmost importance, and we would especially emphasize the proint that it is undesirable to buy from any except nurseries known to be reliable. There are some who are rather careless in their methods of business. Ninety-eight per cent are honest, but watch out for that remaining two per cent.

There is an organization known as The American Association of Nurserymen which guarantees a square deal to every person purchasing fruit trees from any member of that association. Therefore, the safe thing to do is to buy only from some member of this association, or from srme nurseryman whose reputation is personally known to the buyer. ()f course, those who know some nurservilan aid know that he is absolutely reliable, should have no hesitation in buying from him, whether or not he may be a member of The American Association of Nurserymen, but those who are not personally acquainted with some nurseryman. or at least know enough about him to know that his business methods are high-class, and that he will give an absolutely square deal, had better buy only from some nursery that is a member of The American Association of Nurserymen. The Southem Nurserynen's Association also has in its membership only those nurserymen who are known to be reliable.

\section{Buy Fruit Trees Early.}

Time to Buy Fruit Trees.-Now, as to the time when the trees should be bought. In the first place, they should be bought early enough in the season so that one may be reasonably sure of getting what he wants. I ike every other commodity, fruit trees are sometimes scarce. Of course. we sometimes find a nurseryman overstocked, but that is not always the case. So in order to be safe, it is always 
advisable to put in the order early in the season, preferably. during September or October, with instructions to ship out at the most opportune time during late fall or winter.

The Kind of Trees Is Also Important.- Keep in mind that what you want to get is a high-class. well-bred and well-grown fruit tree. Buy it on this basis and not on the basis of how much cord wood it contains. We believe that entirely tom many people who are not acytiainted with the best methods of fruit culture, think that what they should do when buying fruit trees is to get the biggest tree possible. This is not the canc: this is not the way to buy fruit trees. becanse the larger the tree, the more severe the shock when it is dug from the mursery row and tramsplanted to the orchard.

\section{Buy Medium Size and Not Large Trees.}

A small fruit tree that is well-grown, clean, straight and free of disease is worth far more than the two or three year old fruit tree. () f course. the murseryman can supply. you with what you want, and will try to do so, hut what you need is the medium size, clean, well-grown fruit tree. and as said above, not one that is hige enough to produce cord wood.

In the case of the preach tree, the une year-old tree is what should be bought. liy one-year-old, we mean a peach tree that is either one vear wh from the bucl, or that was budded in June and (lise wp and sold the following winter. ()n the whole, we shomld say, tell the murserymen that what you want is a nedium size, Well-grown tree rather than one of the onder and larger trees that so many penple often insist on having.

Buyers Are Protected. - It is recluired that all of the nurseries in the various states be inspected by the State Poard of Entomology lefore they can ship trees. This is done in order to insure, as far as possible. that fruit trees will not be sent out that are infested with insect or fungous pests. The huyer of fruit trees is protected as much 
as possible by the State Boards of Entomology, but in order to insure even further protection, be careful from whom you buy and be sure to buy only from those numserymen in whose word you have confidence. And here again we get right back to this matter of buying from members of the American Association of Nurserymen, or Southern Nurserymen's Association because the rules of their own organization denand that a customer be given what he buys and in as nearly perfect condition as possible.

Buy Only From Nurserymen of Known Reputation.- IVe do not wish to become tiresome on this subject, but we cannot close this chapter without again warning those who would produce good, high-class fruit in the home orchard. to give very serious consideration to this matter of the kind of trees that are bought. Do not purchase from these "wild cat" agents who agree to set a certain number of fruit trees and come back and spray and prune them for five years, for so much money. In ninety-nine cases out of one hundred. agents who sell in this way are doing a crooked business, hecause reliable, up-to-date nurserymen do not sell fruit trees in this way. And, as a rule, the person who sells then this way will never be seen by those purchasing the fruit trees after the trees are paid for. There are good fruit tree agents; there are honest ones representing honest nurserymen, but they have credentials which will show that they have authority to represent these high-class nurse:men. Don't fool with these "flim-flam" agents who offer some. thing that reliable nurserymen do not offer. 


\section{CHAPTER IV.}

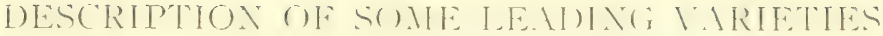 OF APPLES AND PEACHES.}

No attemet is marke in this chapere to describe any latrese number of apples and peaches. Feither is there an effort mate te ger inte a rery technical deseription of the ratrieties. but we helieve something alout the size. Haver, kepping qualities, etc., should be helpful.

The following seven varieties of apples are probably those most commonly planterl in the Senth: Early Harvest. Red June. Horse, Siagman II inesap), Mammoth lilack Twise II inesap and lates. Ire shall therefore sive hrief descrip) tions of these seven varieties.

'The Early Hare'st is one of the olel stand-hos for early apples. It is rellow and medimulares. The Harom is most

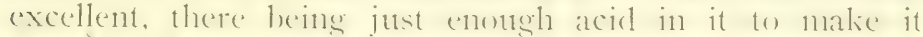
desirible from this standprint. It hears as nearly every seatson, gear in and year ont, as alnust any apple we know.

The Red Jume is one of the best known eatr apples throughout the Somth and, as its nane indicates, usually ripens in Inne, although in the nuper putions of the South. it may not ripen until Inly. It is non a round apple, but is more nearly obloms, and nuedium size. The quality is thoromshly woud, and on acount of its earliness and sither sood qualities, should be planted extensively in the Sonth

The Horse Apple is one of the best finownes smonner apples in many sections of the south. It is a latere apple somewhat of a sreenish yellow entor and is very acid. It msually ripens from very late Jnne thremeh July and inte lugust, and is a most excellent hearer and a comd lieener.

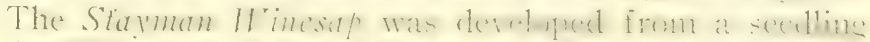

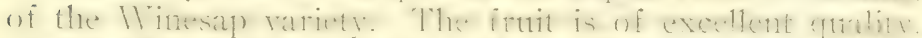
ancl sulali or nuedium in sime. It is reel in color am $\mathrm{i}$ s said to do better on poor sril and lo produce a strongere tree thatn the parent-the 11 inesap. I ike the II inesaf, it is one wi the very best apples. 


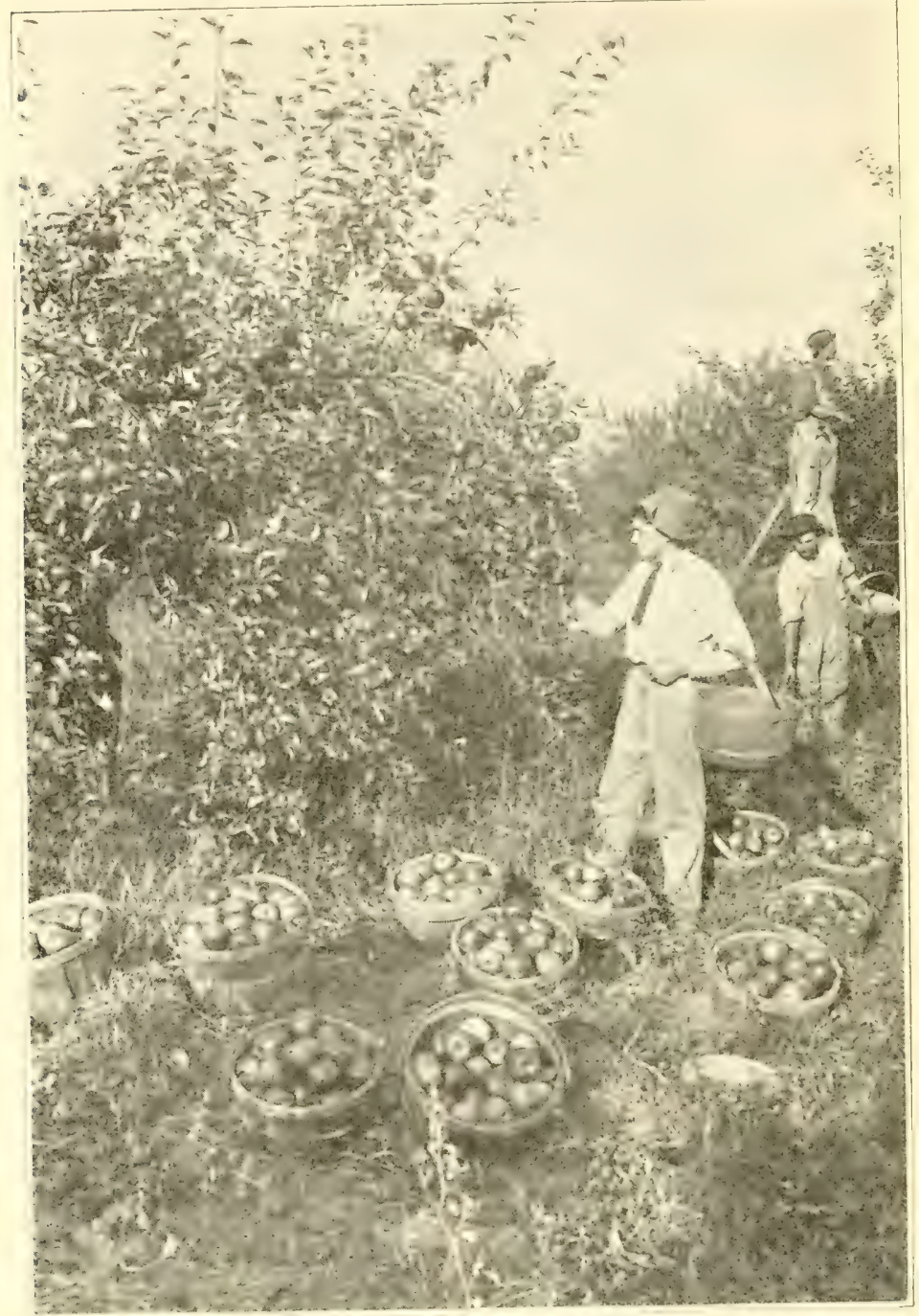

APPLE PICKING SCENE 
The Mammoth Black Tatiy is one of the largest varieties of apples grown in the South. The skin is a very deep red but the flesh is slightly yellowish. It is a very productive variety, an excellent leeper, and therefore a goonl conmercial variety, as well as a good one for home use.

The ITinesap is indeed one of the very best late varieties of apples for the South. It is medium in size, red in color. and a most excellent keeper: In quality, it is doubtful if any apple grown in the Sonth exceeds it, and it is by all odds, one of the very best for the South.

The Yatcs is a small apple, but one of the surest and one of the heaviest bearers that we have. It is a red apple with little whitish dots all over it, and the Hesh is yellow. It is an excellent lieeping varicty and the quality is good. Although this is a very small apple, it is one of the most dependable varieties that we have.

\section{DESCRIPTION OF SUME OF TIE IAEAING \ARIETIES OF PEACHES.}

The Malfluarer is one of the best of the early peaches. The quality, however, is comparatively poor, as none of these very early varieties possess any real quality. This variety, however, colors up to a very red color and looks good. It is a good shipper and on account of ripening early, is a very desirable variety either for the home orchard or for those who are shipping to the local or distant markets. Although it is one of the earliest varieties we have, it is a late bloomer and therefore often produces a crop of fruit when some of the other varieties get killed. The merits of this variety are its earliness and hardiness.

The Carman is a large peach, ships well, and the flavor is good. On account of the tough skin it is considered one of the leading shipping varieties. The skin might be described as a creamy, whitish color. It is one of the earliest standard varieties, and in the central part of the South usually ripens right around June 15. 
The larly belle or Hiley is one of the leading comunercial varieties of the south. It colors up quite well, is large and a creamy white. It is not only a good variety for shipping purposes but it is an excellent variety for the home orchard. It ripens soon after the Carman.

The Belle of cicosylu is one of the leading commenereial varieties also, and is planted quite extensively. It is a very large peach, most attractive in appearance, possenes an excellent flavor, and in quality is second to no peach srown. It is a heary bearer and might be considered one of the very best of the two or three leading varieties of peaches for the South, whether grown commercially or for the home orchard. It ripens just after the Hiley.

The Ellberta is probably the king of all peaches. The quality is not altogether so gond as some of the others, but on account of the large size, excellent keeping qualities and excellent shipping gualities, it is certainly one of the leading -if not the leading commercial variety. The flesh is yellowish in appearance and the stin is more or less yellow, with some red spread over it. It is an excellent variety for camning and for eating. even though the quality is not quite equal to the Hiley or lielle of (ieorgia. No home orchard is complete without some of these. 'They ripen in the middle part of the South right around July 15 th and follow rather closely the Belle of Georgia.

A variety that ripens just a few dass after the bilberta. and a comparatively new variety, is the $J$. H. Hale. It is a very large peach, larger than the Elberta, and many say that it possesses better quality and better flavor than the Elherta. The Hesh is yellow. It ships well and is, all things considered, me of our leading varieties, even though it has not been linown for many vears and is not so well estab)lisherl as the Elberta, the Ililey, and the Belle of Georgia.

A variety that follows the Eiberta rather closely in ripening is the chinese Kliny. This is a very large variety that is slightly yellow in color with red at the tips. It is a clingstone variety, it is quite juicy, and one of the best of the late varieties. 


\section{CHAPTER V}

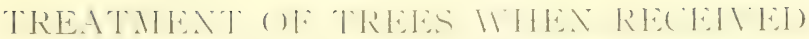

\section{FROMI NURSERY.}

Set Trees Immediately Ifter Arrisal. It is wi the

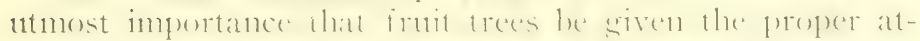
tention immediately after they are received from the nursery. Of course, the proper thing to do is to set them at once, but very often this camnot be done. 'The ground

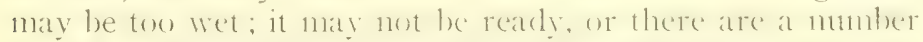

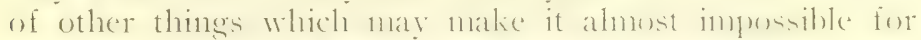
one to set the fruit tress immediately after reecivine them. and the prorpose of this chatede is to ontline luritefly just what may be done in a case of this kind in orele to perevente damage to the young trees.

In the first place, as soon as notice is received from the

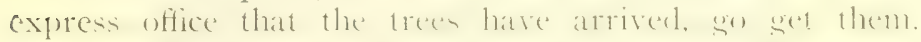

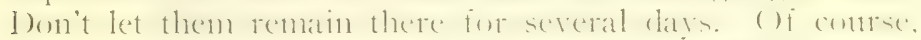
when they are well pactied they will here sereral rlats in

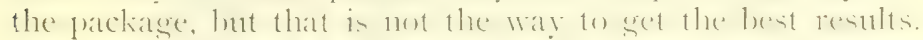

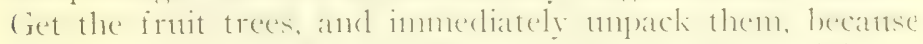
the roots are hound ap tiehtly in the pacling material and the sonere they are releated froms this material the loetter.

Moisten Roots fil hon Trees Arrive.- It for atly reation

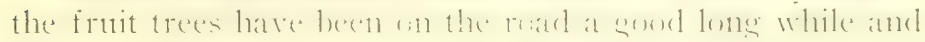
the packing material aromed the routs has dried ont and

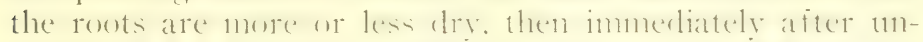

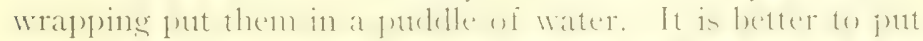

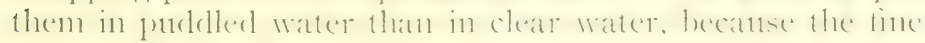
soil particles will cling to the rents and therelog help to hold

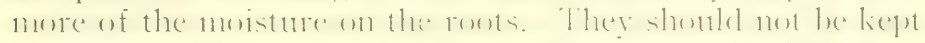

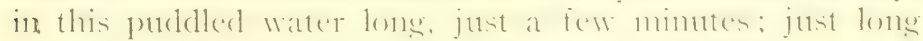
enough for them to become thoroughly moistened.

The above treatment should be given whether or not the trees are to he set immerliately, lecanse the ronts should never be allowed to dry out at any time. If they are not to be set inmediately, they shombl be "hecled in," which is nothing more nom leas thate planting the trese in trenches. 
How to "Heel In" Fruit Trees. - To properly "heel in" fruit trees, dig a trench rather wide and six to ten inches deep. Place the roots of the trees in the trench so that the trees will be in at an agle of about 30 to 35 degrees. It is better to put them in this way than to set them straight up, but of course if one wishes to dig a deep enough and wide enough trench they may be set up straight. But that is not the usual method of "heeling in."

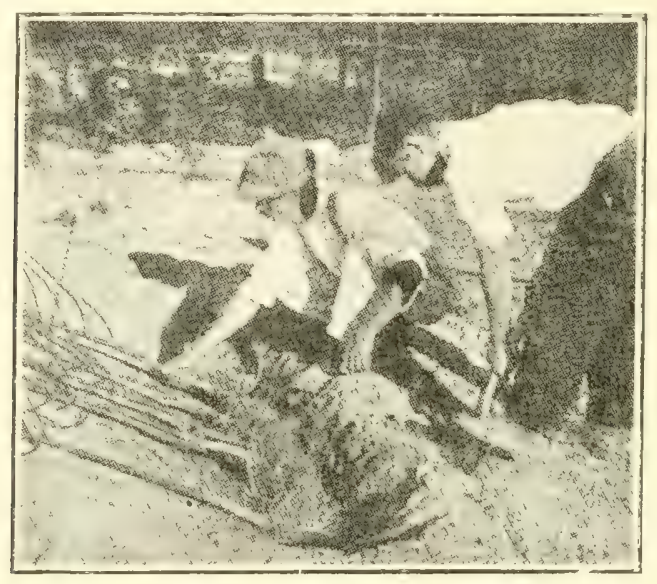

"HEELING IN" FRUIT TREES

After the trees are properly placed in the treach, throw the dirt in on the roots and pack the soil lightly. It should be packed sufficiently to hold the moisture around the roots. By "heeling in" the fruit trees in this way, they can be kept several weeks during the winter time without material damage resulting. It should be liept in mind, however, that, other conditions being equal, it is always best to set the fruit trees immediately after they are received.

\section{Proper Method Handling Fruit Trees.}

Don't Expose Roots to Sunshine. - In setting the fruit trees, be careful not to allow the roots to be exposed to the 
sunshine. The have seen many follis in planting fruit trees go ahead and dis the holes and leave the fruit tree roots exposed to sunshine and air a half day. or even a daty or two, hefore the trees were set. This is inviting disaster: don't do it. Ion't put the frotit trees where the rents will be exposed to smolnine even for ten minutes before they are to be set.

A good methorl is to put the fruit trees in a harrel or bucket of water and lieep them there until ready to set. Of course, they should not be put in water any greater length of tine before setting than is necessary, and it is better to use the puddled water, or dirtl water, than it is w use clear water, for the reasme mentioned in the first part of this chapter.

Nerer Let Roots Become Iry.- The point to keep in mind is that fruit tree roots shomld never be allowed to dry out. More frutit trees die from this trouble when being set than probably all others combined, especially when the planting is done by inexperienced persons. It is comparatively easy to get a fruit tree to live if it is properly set and the roots have not been allowed to dry ont. But if the roots have been allowed to dry out, then it is a mighty hard joh to get any reatsonable number of the trees to survive. Ife cannot emphasize this proint too strongly that the roots should not le allowed to dry ont, and keep in mind that the nurserymen nstally deliver these trees to vou with the roots in sond shate and moist, and it is 115 to goul to see that they are not allowed to dry out from the time you receive them until they are set.

Trees are more or less like a lish in that they cannot live very long if liept away from moisture. Take a tish out of water and it surne dien: lieepe the fruit tree routs exposed to air and sunshine for a little while and they will die also. Therefore, mark it down that you must lieep the roots moist and not let them dry ont if you would succeed in transplanting fruit trees and have a good percentage of them live. 


\section{CHAPTER VI.}

\section{SETTING FRUIT TREES.}

Lay off Orchard in Rows. The tirst thing to do when ready to set frutit trees is to stake wif the tield, or laty off the rows by whatever methen seems best. It is highly infportant to have the iruit trese in straght rows, and they shomld he strateht in evers direction. In other words, they shomld check row. ( ) f collrse, frout trees in straight rows will not produce any nure fruit than will trees set in croskel rows, but an orchard where the fruit trees are all in straight rows lowlis so very nutuch lester. that it is worth while to put them in straight rows.

(of comse, where one is planting a home orchard and different kinds of iruit are planted in the same field, and maturally some farther apart than others, it is impossible to check row them and have them in straight rows in every direction. Put one can put theme in straight rows in one direction, and this should be done.

Of course, peach trees will be one distance, apple trees another, and so on down the line. This would make it inposible, as said above, to get them in straight rows in all directions, but where one is planting, say half an acre or more of one frute then the trees cate be put in strateht rows so they will check row and he straisht in every direction that one may look.

Put Trees in Straisht Rows. Ne wish to mose that those planting the lesme orchard give sume attention to this matter. lecatese frout trees in a cromked row elo not look half so well as when in a statioht rum. It is all a matter of looks. lut then it is worth while and it costs but little effort to get them in straight rows.

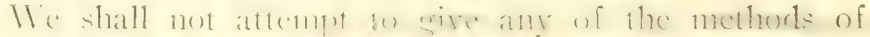

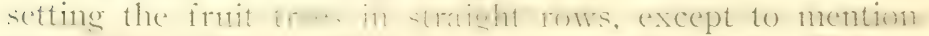

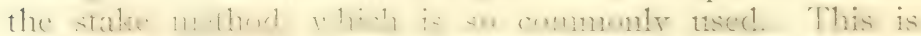

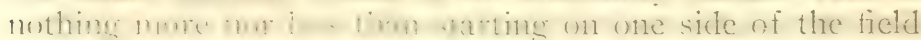
with at high stalie where the first frut tree is to be planted. 


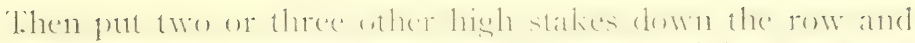
in line, so as to get them exactly in a straight row, and then set small stakes where each fruit tree is to go. Still

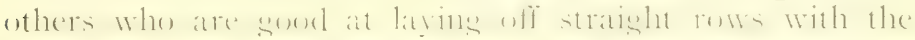

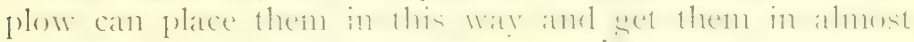
exactly a straight line.

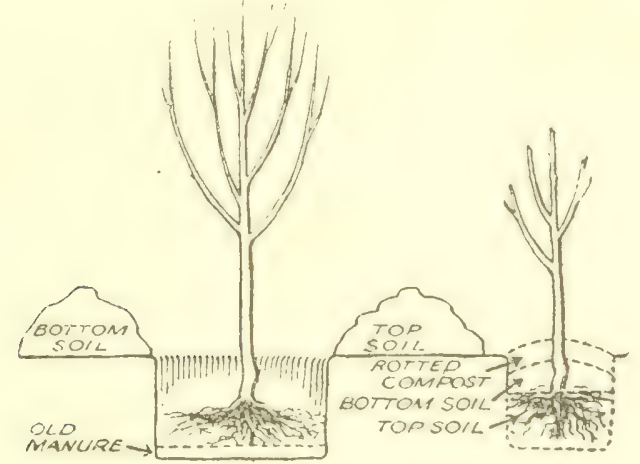

The above illustrates a good method of setting fruit trees. Also note that the tree at the right is the same tree as the one at the left, the only difference being that it has been set and properly headed back.

\section{DIGGING THE HoLES.}

Method of Digging Iloles. It in fathe (tembonty to dig holes that will not allow the rests plenty wi stater. Dies the

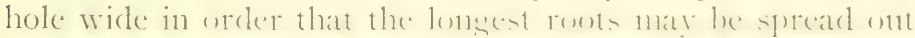
in their natural josition, and then not reach the edge of the

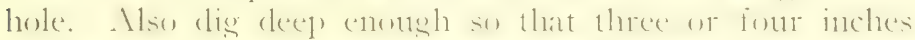
of loose soil or well rotted manture mal be put in the bottom of the hole for the roots to rest on. This is far better than

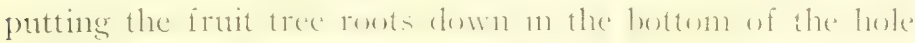
resting on hard, compact soil.

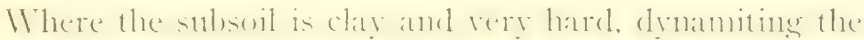
hole will prove of value. A stick of dynamite put two or three feet betese the surface of the soil risht where the tree 
is to be planted and exploded, will serve to crack up the subsoil and enable the young tree to grow off to better advantage.

But whatever method one adopts to dig the holes, be sure they are dug deep enough and wide enough to permit the setting of the roots in their natural position. They cannot and must not be put in the hole in a wad if one would succeed in having a majority of the trees live.

\section{Don't Carry Trees to Orchard Until Ready to Set.--One} should not carry any of the fruit trees to the orchard until the actual time of setting, becanse if this is done the routs will be exposed to the air and sunshine, and as said in a previous chapter, this absulutely must be avoided if one would succeed in having most of the trees live.

Talie the whole bunch of trees to the orchard after the holes are dug and you are ready to set the trees and put the roots in a puddle of water; then take a few at a tine and put them along in the holes where they are to be set, and if they are liable to be exposed to the air and sunshine for a half hour, throw a little dirt on them. This may sound like a lot of trouble, but it is well worth while, because we must lieep in mind that if the roots are once allowed to dry out, it is "goodbye" fruit trees.

Prune the Roots of Trees.-Before setting the trees, the routs should be pruned. Cint off all dead or injured roots. I'here a root is broken or mashed, it should be cut off. Make a smooth cut and a sloping one, instead of cutting straight across. Also cut back any of the roots that may be unusually long. We often see a fruit tree with an abundant root syste11, but with two or three roots considerably longer than the others. Cut these back so as to conform approximately to the length of the main root system. All of the fibrous roots should be cut off, because they are either dead, or soon will be, and cannot do any further good. 


\section{Proper Way to Set Fruit Trees.}

Pack Soil Tightly Atout the Roots. - Now, when ready to set the fruit trees, put a shovel or two of soil or well rotted manure in the botom of the hole and tamp, either with the fout or a tamper. Put the tree in the hole, letting it stand exactly straight up, and do not have it leaning to one side or the other. Throw in the soil, a few shovelfuls at a time, taking care to put in the top soil around the roots and not the clay soil that was thrown out from the botton of the hole, and remember it is important to pack it tightly around the roots. One can use the feet for packing, but the end of a scantling, or other form of tamper, will usually be more satisfactory and less trouble to handle. I Don't pile in a big pile of dirt and then prack goosd and hard, but put in just a few showelfuls at a time: pack thoroughly and then add a few more shovelfuls and lece on in that way until the hole is full.

After all of the roots are covered with soil and the soil is thoroughly tamped, then fill in the hole and pack less tightly than the soil was packed aronind the roots. Of course, it should be fairly well packed right on up to the surface of the ground.

At the best, the soil is woing to settle some, because it is almost impossible to pack it as tightly as it was before the hole was dug, and therefore, one should pile the soil up from two to three or four inches above the surface of the ground, leaving the top inch or two of soil loose. If the weather is dry it is a sood plan to mulch the newly set trees with manure, hay, grass, or other sinilar material.
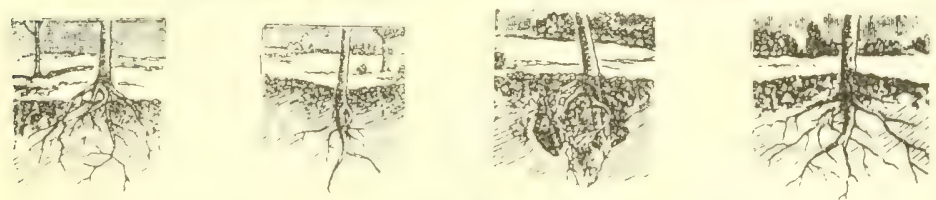

Showing the right and the wrong way of setting fruit trees. On the left the tree is not set deep enough, and the second one from the left is set too deep. The third one from the left shows the bad effects of bunching up the roots and setting the tree in too small a hole. At the right the tree is properly set as to depth and the way the roots are spread out. 
Depth to Set Trees.-... The iruit trees should be set, as at mule, about one and a half to two inches de+per than they were in the nursery row. ()ne can tell by looking at them how dece they were in the nursery row, and should keep this point in mind.

While setting the tree, watch it every now and then to sec that it is setting 11 ) struight and not leaning to one side or the other.

By following carefully the directions that have been given in this chapter as to how to set fruit trees, and studying the illustrations, there is no reason why anyone should not be able to have the majority of the trees live. sume of the things that we hatre recommended may somnd munecessary to some follis, but we assure you that they are 10 t unnecessary. It is the attention to all of these little points that will nean the difference between having nearly all the trees live and a good many of theme die. I fruit tree is something to last for many years, and one camnot be too praticulat at the time of retting to set properly and set them started off to the very hest possible advantage.

\section{Distances for Planting Fruit Trees.}

Apples

Cherries

Plumi and Pracher

I)warf I'cary

Dwarf Apples.

Grapes

Raspberries, Blackherries and Dewherries....3 to $4 \mathrm{ft}$. by 5 to $7 \mathrm{ft}$. apart Strawberries, for field culture....1 $1 / 2$ to $31 / 2$ feet by 3 to 4 feet apart Strawberries, for garden culture.
30 to 40 feet apart each way 20

16 to 20

10 in 12

10 to 12

8 to 10

Number of Trees ON AN ACre.

30 feet apart each way

25 feet apart each way.

20 feet apart each way.

18 feet apart each way

15 fect apart each wav

12 feet apart each way
5010 feet apart each way. 708 feet apart each way. 1106 feet apart each way

1355 feet apart each way. 2054 feet apart each way. 3003 feet apart each way.
435 680 1,210 1,745 2,725 4,840

RuLE.-Multiply the distance in feet between the rows by the distance the plants are apart in the rows, and the product will be the number of square feet for each plant or hill: which, divided into the number of feet in an acre $(43,566)$, will give the number of plants or trees to the acre. 


\section{CHAPTER VII.}

\section{HEADING B.ACK TRUIT TREES AT THAE OF SETTING.}

How to "Ilead Back" Fruit Trees.--Tu( , ften people set fruit trees and allow them to grom in the natmol forme This is not the best thing to do. I fruit tree should have what is known as an "open center," with the branches spreading ont. If the trees are not headed hack at the time

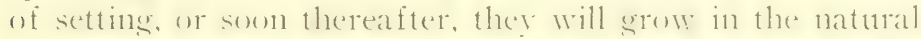
thape that is to sis. upright. With the matin stems in the center-atnd will groum entirely tor tall. Le'pe in mind that what is wanted is the "ofene center" with no matin stem. but with three of live matin branches comlins ont forme sereral sides of the tree.

Don't let anyone try to make you believe that you will injure vene frutit trees he crotting ont the tope at the time of

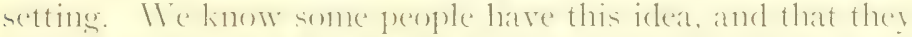
think the propere thing to do is let a fruit tree grom in its natural shape. This is not the case, because if it is not headerl hack it will rom 11) atnd hecomme a slender, tallstowing tree that will probuce far less fruit than would be produced if it were headed back and pruned.

\section{Cut Out Top of Tree Immediately After Setting.} Therefore, colt out the tor) inumerliately after planting. The height above the ground at which to malie this cat depends on the kind of fruit, size of tree, etc.

Is a seneral rule. however, peach trees shombl he headed back to within $1+\mathrm{t}$, 20 inches of the surface of the ground. Some head them back as high as $2+$ inches. but we think from 14 to 20 inches is about right.

IIth apples. the cuts should te made slightly hioluer frotul the sround, and the proper height is from 20 to 24 (1) 28 inches. Sinne head the apple trees back as much as 32 inches abore the surtace of the swound, but ath arerage of 20 to 24 inches is about right. 
"Heading back" is nothing more nor less than cutting out the top. This cut should be a slanting cut and not square across. Nake the cut just as smoothly as possible and not more than a quarter of an inch above a good live bud.

Nurserymen Will "Head Back" Trees. -Those who do not clearly understand just how to head back the peach, apple and other fruit trees can have a sample of this work done by the nurseryman from whom the trees are bought. Nurserymen will usually head back one tree of each lind as a guide for those customers who request that this be done. Anyone buying fruit trees and not being certain as to how to do the work, will probably find it advisable to request the nurseryman to (o) this before shipping the trees.

There is very little real work attached to this "heading back" process, but the important point is "knowing how to do it." ITe believe by carefully studying our discussion on this subject and the illustrations showing how to head back fruit trees, and having the nurseryman head back one before shipping, anyone can do the work.
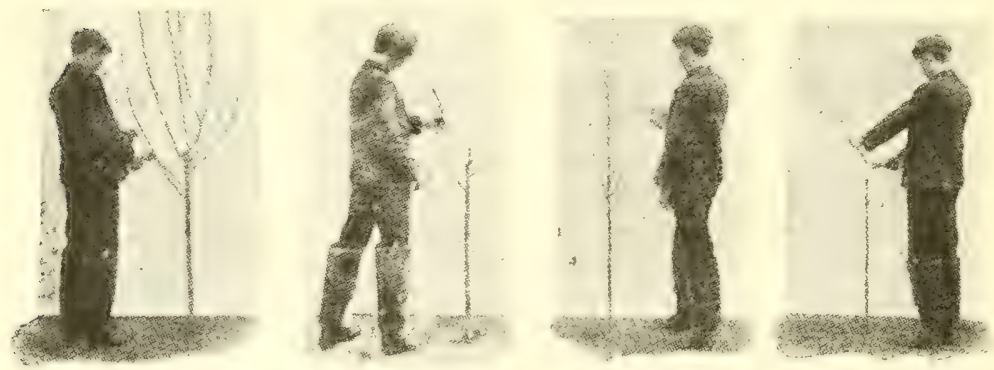

The two illustrations to the left show "the before and after" of pruning a newly set two year old apple tree. The two at the right show a newly set one year old peach tree, before and after pruning. These two illustrations show exactly how to prune buth large and small fruit trees immediately after setting. A small apple tree should be pruned just like the peach tree shown above. 


\section{Pruning Newly Set Fruit Trees.}

How to Prune Peach Trees.-- In the case of the peach. especially when a one-gear old is hemeglanted-and this is ats old a peach as should be planted as a rule all of the sirle hrancles shomlel be trinneled wit and everythine that will be leit after it is headed back and the side branches trimmerl
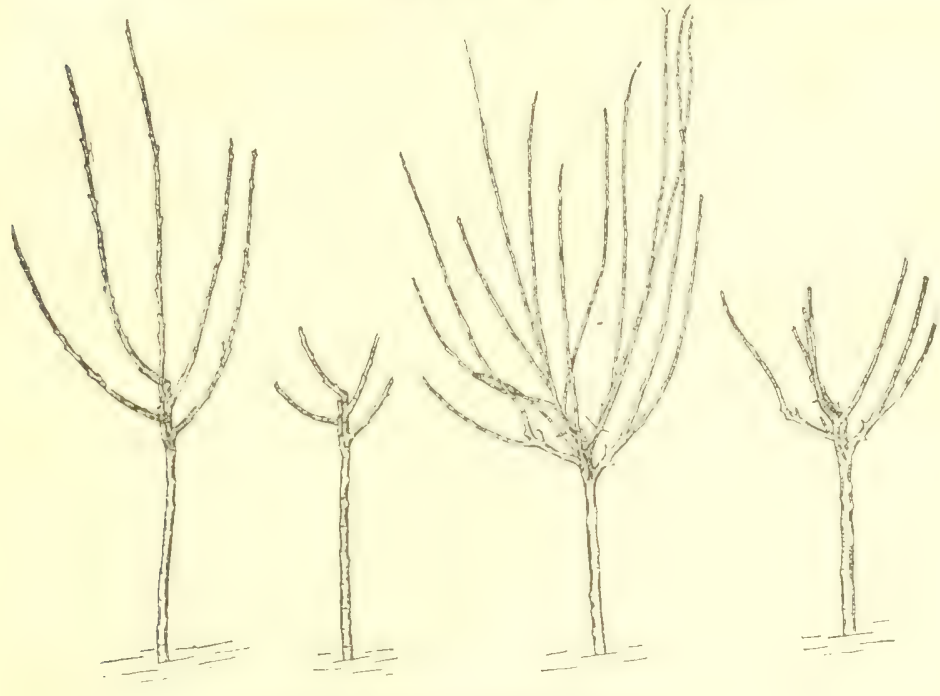

BEFORE, AND AFTER PRUNING

The two illustrations at the left are newly set fruit trees (comparatively large) before and after prtming. The two at the right represent the same tree after one year's growth has taken place and the pruning has been done.

off is just a little whip from 14 to 20 inchees long. Nom, don't heeone alarmed and think von have rumed vour peach trees if your (lo this, becanse vou havent. Of conrse, if you should happen to be setting a two-year old peach tree, or one that is especially large and has well formed branches, 


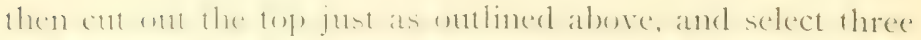

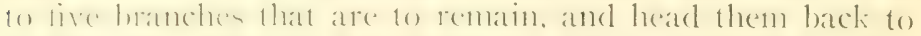

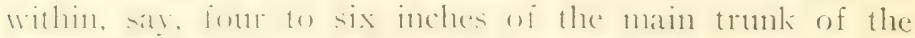
tree.

How to Prune Apple Trees.-.. Ilhen setting afples, where the two-veat old tree is often used, it may be desirable to kave lle branches rather than to trim them all ofl and depend on selecting the main hranches from the next year's growth. In case these are not all trimmerl off, select (as in the case of the peach) three to five of the best located branches for the matin body of the tree. These should be headed back, sily. Within five to six or seven inches of the trumk of the tree. () f contse, when heading back the branches, talie the sane precatition of cutting just above the buel and with a slanting. smooth slope as when cutting out the top.

\section{Select Main Branches With Care.}

In selecting these three to five branches for the main berly of the tree be careful to have them properly distributed aromel the tronk of the tree and not directly opposite each wher. Say if one branch on one side is just 12 inches above the surface of the ground, let the next one opposite he cither 10 or 1 inches, etc. If these branches are directly oppesite each othere or all coming from the trunk of the tree near the same place. the tree will be more liable to split than if they were scattered up and down the trunk within a space of 6,8 or 10 inches. This is a proint that should be wiven careful attention, because it naty very well mean the difference between a tree that will withstand heary winds and heary crops and one that will be ruined by them.

Tree Takes Permanent Shape During First Year.-Too much attention camnot be given to : first, the proper heading back, and second, the placing of the branches around the 
trunk of the tree: because it is the first year that a tree takes on more or less of its permanent shape. It can be pruned so as to conform to alnust any desired shape during the first or second year, hut if not started in the right form immediately after planting, then, neglect at this tine cannot be made up for completely in the future. The pruning of the fruit trees after the year in which they are set out will be discussed in the following chapter. 


\section{CULTIVATING THE ORCHARD.}

\section{Thorough and Frequent Cultivation Necessary.--} Whether the orchard is a latge or small one, it may just as well be aceepted ats a fact that to succeed with it, cultivattion, and very frequent cultivation at that, munt he resorted to. There seems to be at common (p)inion anmong many folks that becatuse apples, peaches, plumes, peats, etc., grow in the form of trees, they do not need cultivation. This is a mistaken idea and one that will invariably result in poor. inferior fruit, if adopted. Trees are just as truly plants as are cotton, corn, tobaccu, ete., and while they grow over a longer period of time, cultivation is just as necessary in order for them to succeed to the maximum extent as it is for the annual plants, like those mentioned above. Therefore, let all who have fruit trees-thoush the number may be small-make up) their minds once and for all that thorough and frequent cultivation must be given if good results are to be secured.

Cultivated Crops May Be Planted Between the Rows of Trees. When the orchard is young, that is, during the first few years after the trees are set ont, it is entirely feasible and practicable to plant some cultivated crops in between the rows of trexs. In doing this, howerer, one should be careful not to plant the crops too close to the trees. Never plant a cultivated crop, or any other crop, close enough to the trees, so that when cultivating the single-tree will cone close enough to knock off the bark. The trees shombl not he touched by the single-tree or bent about. Put the nearest row of cultivated crops sufficiently far away from the trees to make certain that no single-tree will come into contact with them.

\section{Crops to Plant in Orchard.}

Leguminous Crops Desirable.--There are certain crops that should never le planted in an orchard, no matter how 
romes the frees mat be, and among these are some of the rapid growing plants like corn. Neither should small grain be sown in the orchard, anless the grain is to be chopped (1) pieces and tumed moder hefore it starts to rum up early in the spring.

Keep Oats Out of Orchard. - Uats is one of the most munatisfactury crops that can be planted in an orchard, muless the crop is cut to pieces and diskerl moler just about

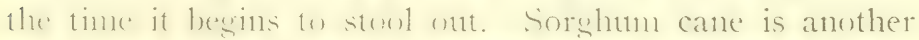
crop that shonle, murler 110 conditions, he planted in an orehard. It drats reng heavily on the land, especially the moristure, and grow- high. like corn, and shades the fruit trees and will do then wntold harm. Therefore, do not plant any steh coups in the orchard, but nse the low-growing crope that draw a lishty on the soril fertility as possible. such an cow poas, on heans, I rish potatoses snap heans. variots truck crops, etc.

Plant Crops That Require Frequent Cultivation. - - In selecting the crop that is to be sown between the young fruit trees, be slle to select one that will reguire considerable cultivation and heary fertilization. This should be done becallec of the fact that it will bring about ideal conditions for the frute trees. liv using a laree amount of commercial fertilizer and by giving frequent cultivation to the crom that is croming in between the trees. there will be sufficient platut ford to catuse the trees to srow rapidly and cultivation will be frequent enomeh to serve this purpose. It is entirely pusilile worow between the fruit trees, for the first twe veatre a sulfichent ammunt of varions kinds of (rops to more than far the cost of the cultivation and the

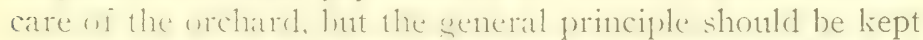
in mind that nu crop that is tall-wrowing, a rank feeder, and that 11 ses a latere anmmut of water, should be planted; and

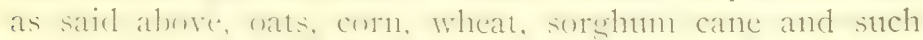
crops as these come under this head. 
36 How to Succeed Witir the Home Orchard

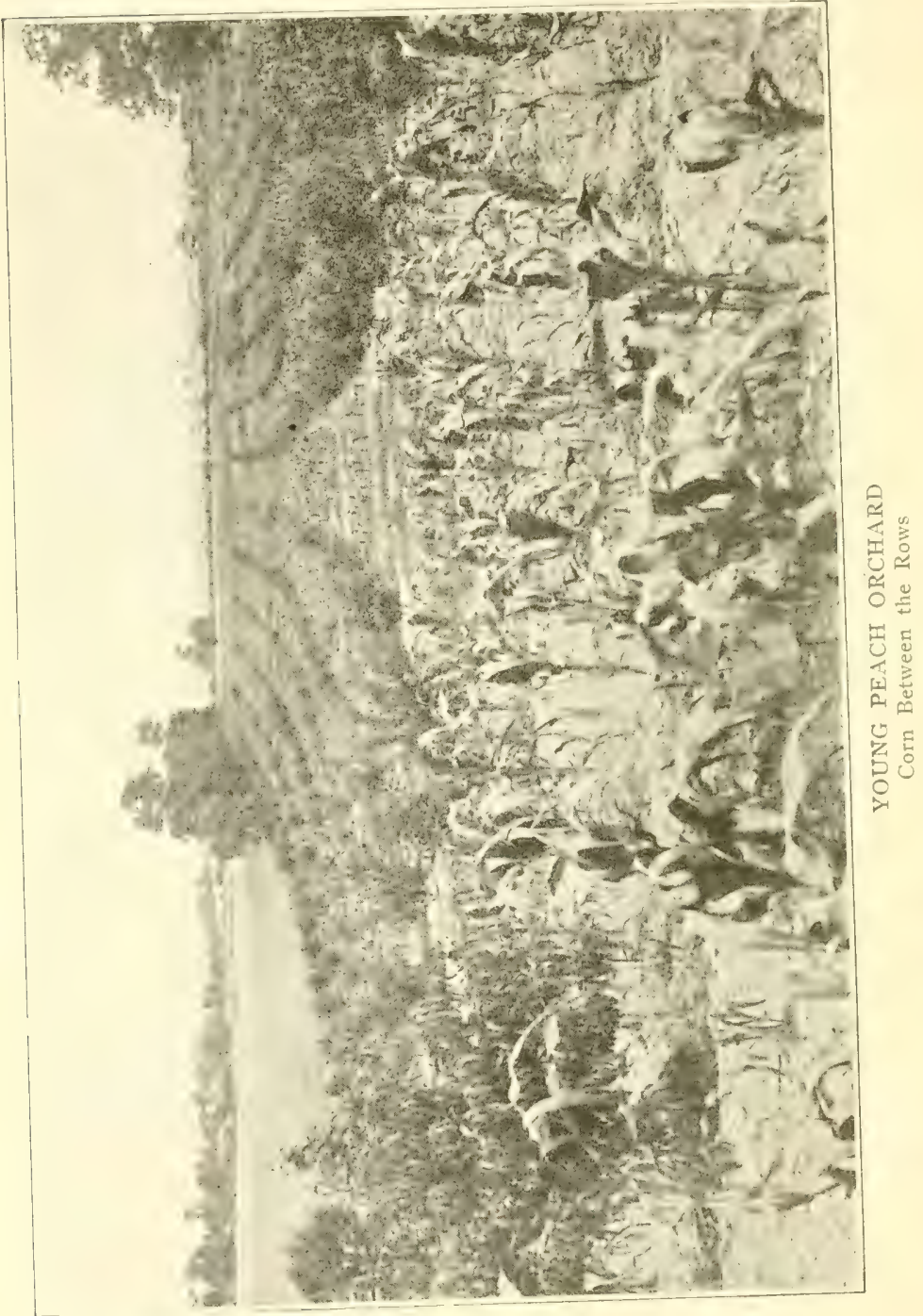




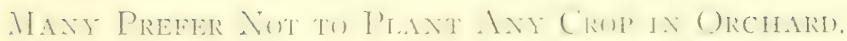

\section{Cultivate As lou Would Field Crops.-- I great 11any} preier inst w plant any cultivated crop) in the orchard erein

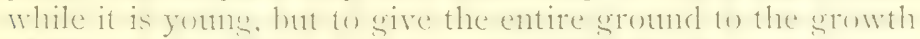
wi the yomne trees. Phere is no roubt but that this is the best wate te secure the maximume results in the shortest time with the iruit tress, hut when this method is aclopted, malie 11) vour mind right now to treat these fruit trees as though

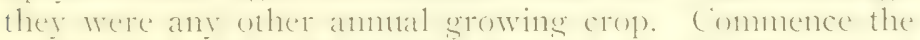
cultivation early in the spring, and continue nut'l well heyond

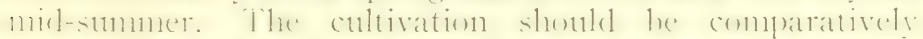

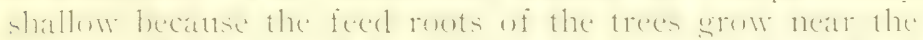
surface of the sromed in oreler to get as much plant foud as pissible, and de(e) cultivation will invariahly do comsiderable harm by breaking off these roots.

Cultivate to Prevent Crust Forming on Surface. - It

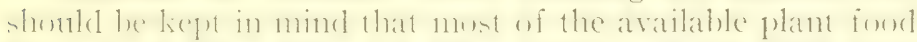

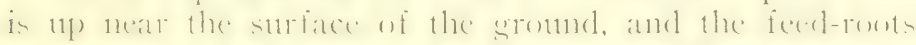
will naturatly find here way to this place. Thus, it call lx chealy $\rightarrow$ (e+1) why it is ingutatet that the cultivation be shallow. () f collse, when the first cultivation is given in

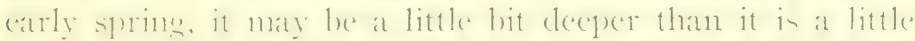

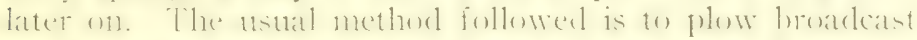
early in the spring with a shallow turning plow. The culti vation following this should le trepuent and shallow, u-ins

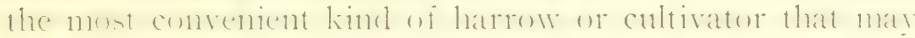

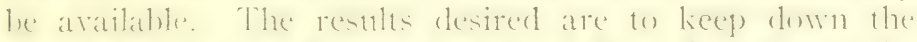
wereds and wass and prevent a crust from formuge on the surface of the ground.

\section{When and How to Cultivate.}

Shallow Cultivation lirings Best Results.-Cultivation

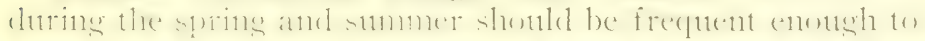

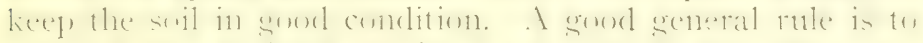
cultivate the wirlatel in the sime semeral wat that gout would some truck (rop). L'sually, this should be given once 
every week to ten days, and sometines more often. It is only by giving the very best of attention in the way of cultivation that the desired restilts can be secured, and those who persist in feeling that a fruit tree is a tree that can "knock" for itself and does not need cultivation, may just as well make up their minds that they are not going to succeed with the home orchard. Of course, it is possible to grow fruit without cultivating the trees, but it is not possible to grow either the maximum quantity, or the best quality, or the most profitable crops of fruit, unless frequent and shallow cultivation is given.

As said above, it does not anlount to so much as to what implement is used in giving this cultivation, just so long as the desired results are obtained, namely, the keeping down of the weeds and grass and preventing the formation of a crust on the surface of the soil. 


\section{CHAPTER IX.}

\section{FERTILIZING FRUIT TREES.}

Use Commercial Fertilizer.- In ninety-nine cases out of a hundred it will be found profitable to give an annual application of commescial fertilizer to fruit trees and an occasional application of stable manure, say once every three to five years. If the ground on which the fruit trees are growing is already quite rich, then an application of stable manure will not he needed so often, but if it is poor. or medium poor, an application of manure every year, or until the trees are well started, will be profitable. In applying this, it will be desirable to scatter it broadcast and build up the fertility of the land, not only immediately around the trees, but of the whole surface.

Use Stable Manure Also.-In addition to building up the soil by application of stable mantre, one can use to advantage the scrapings from the fence corners about the lot, yard, etc. Iust scrape up and scatter broadcast in the orchard any time during the winter, and plow under at the first plowing in the spring. ()n the average farm where only a small orchard of a $\mathrm{few}$ acres is to be fertilized this way, there will be plenty of scrapings from about the house, wood shed, barn, etc., to lieep the orchard in aood condition.

\section{MANURING THE ORCHARD.}

Grow Leguminous Crops in Orchard.-In addition to applying stable mantre. scrapings, etc., to the orchard, the general fertility of the soil can be added to, and should be added to, by growing both stmmer and winter legumes in the orchard. By cultivating the orchard until mid-stmmer. say until late June or early July, and then planting cowpeas or soy beans, much fertility will be added to the soil by these crops. After they are harvested in the fall, sow down to some kind of clover, either crimson (or in some sections red clover), and let these grow during the winter. 
Then turn under in early spring. By practicing this method a few years, the general fertility of the soil will be very sreatly enhanced, especially in nitrogen, which is the most costly form of fertilizer.

Small Grain Crops Prevent Leaching of Plant Food.- lt is very desirable to have something growing in the orchard during the winter, and in case you are annong those who think you cannot grow any of the clovers, then go ahead and plant some of the fall grain crops. such as wheat, oats. or rye in the early fall, taking special pains to see that these are thoroughly chopped to pieces early in the spring by a disk harrow, and turned under. While the small grain crops will not add so much fertility to the soil as clovers, get they will make use of considerable plant food that will otherwise be leached ont during the winter, and will store it typ for future use of the fruit trees.

\section{Kinds of Commercial Fertilizer to Use.}

Much Nitrogen Needed.- If the orchard has been liberally fertilized with stable manure, etc., as ontlined above. then a commercial fertilizer with a comparatively small amonnt of nitrogen and with a comparatively larege amount of phosphoric acid and potash should be used. In a case of this kind, we should say that a fertilizer analyzing around 10-1-t would be about risht. However, if the sround is not rich in nitrogen, then considerably more nitrogen should be had in the commercial fertilizer, and one analyzing around 10-4-4, or 10-3-4, would be about right.

Top Dress in Spring.-- In arldition to siving a liberal application of the complete fertilizer early in the spring, an application of nitrate of soda or stuphate of annmonia siven in late spring, just as wrowth is hecoming rapid, will prove highly desirable and profitable as a rule.

Time to Apply Fertilizer. - The proper time to apply the complete commercial fertilizer is very early in the spring when the first cultivation is given. This should be wsually 
atsut the time the hute lexin to swell in the spring. Tse this enmmeral fertilizer hy scattering it hroadcast aroumel the tree and cultivating it in. I)on't try to scatter it over the whole gromel. hot merely in a circle about the tree. commeneins from two to six or eight fect from the hase of the trumb wi the trees, depending on size of tree, and scattering it ontwarl 10 a distance of sereral feet beyond the spread of the branches.

Where to Apply Fertilizer. - Seep) in mind that the feed routs of the fruit trees ate not rieht anear the hase of the

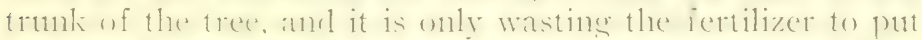

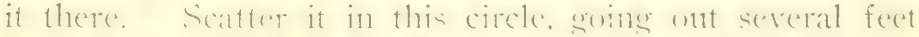

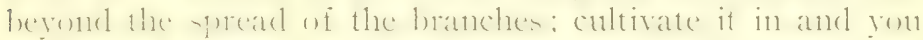
will have it where it will fo the mose goode () f course, the

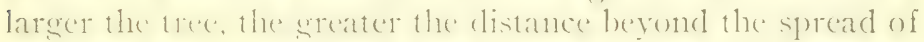
the branclies the fertilizer should be applied.

\section{Amount of liertilizer to Use.}

Fertilizer Needed baries With lge of Trees.-. l mally.

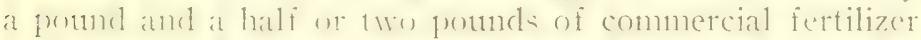

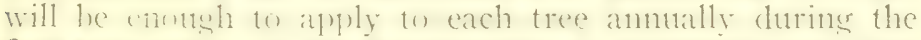
first 2 wo years. It shomld be sradtually increased until five.

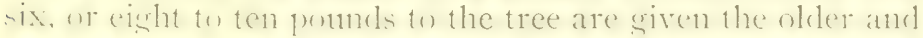
latrer trees. In arldition to this, nitrate of sola wr sulphate of ammmonia siven later in the sprine shombl be applied at.

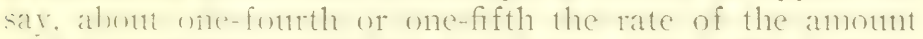
wi the commlete commercial fertilizer. The fortilizer given to the ventue irute trees before they reach the heariner aese should combain a heary potoportion of nitrosene and a limited anoment wi phosphoric acid and potash. Then as the fruit trees commence bearing. as a rule it will pay well to decrease the porportion of nitrogen and increase the propurtion of phosphoric acid and potash.

Chanse Proportion As Trees Mature. - Romehly spealiing. While the arees are young and before they reach the hearing ase, the fertilizer containing, say only 5 or 6 per 
cent of phosphoric acid and 1 or 2 per cent of potash, and 6 or 7 per cent of nitrogen should be used, because it is at this time that the principal thing desired is growth in the trees: and becanse of the fact that nitrogen is the part of the fertilizer that produces the growth, this substance should naturally predominate. Mso, when the tree reaches the bearing age, it is equally inportant to reduce the amount of nitrogen in order to prevent too rapid growth and to increase the amount of phosphoric acid and potash, in order to produce the proper amount of fruit, give it the right color, etc.

Anyone who will give a little careful study to the subject can fertilize fruit trees in such manner as to greatly enhance the value of the home orchard. 


\section{PECAN GROWING IN THE SOUTH.}

Never Plant Seedling Pecans - The we thing that should be remembered about pecan growing abuve all others is, that the seedling trees should not be planted, but the budded or grafted varictics should always be used. The seedlings will almost invariably produce small, inferior nuts. And then, ton, the secolling tree does not usually bear antil it is from twelve to fifteen, or in many instances twenty years of age: whereas, the wrafted or budded varieties will. under good conditions, bur from three to five years after the trees are set out. Therefore, we wish to emphasize this point above all others. Don't let anyone tell you that the thing to do is to plant seedling pecans, because that is absolutely wrong.

Pecans Should Have Well Drained Soil.-Pecans will succeed in the South almost anywhere that cotton will grow well. It is true that the very best results are secured on the Coastal Plains; yet, it is equally true that excellent results have been secured from these budded or srafted varieties of pecans in almost all sections of the cotton belt. The pecan lowes a moist soil, and yet it absolutely demands a soil that is fairly well drained. There are some varieties, of course, that will grow fairly well in bottom land that is overflowed, but if it is land that is water sogered at all times. then, it is very seldom that the pecan will succeed in a big way.

Few Trees Will Supply the Home Need...-IVe believe that every person in the cotton helt, especially those in the lower section, should plant a few pecan trees in connection with the home orchard. As a rule, these should be set from 50 to 60 feet apart, and it will take only a comparatively small number of trees to produce all that a family will need and to supply the local market in a linited way. If the trees are set 50 feet apart with the first and the last row only 15 feet from the edes of the field, then, only 80 trees 
wornld be required to set five actes. The further fact that the pecan trees will not take $u p$ all of the gromend for several vears, makes it all the more important that at least an atce or two be planted on every sonthern farm: at leats those in two-thirds of the lower cotton belt.

Plant Cultivated Crops Between Pecan Trees.- l'ecan frees should never be planted closer than 50 fect apart. according to our way of looking at it. Of comse, there is no need to let then wtilize all the ground while youns. but one can go ahead and plant any of the cultivated crops in between the trees, or tigs, plums, grapes, peaches, etc.. call be planted in between the pecans. Onr preference, homerer. is that some of the cultivated crops. like cottun, cablatge, beans, soy beans, etc., be planted in between the fecan trees; because in this way fairly clean cultivation will le given and a reasonable amount of fertilization will also be given. When planting this way, however, one shendel deave at strip of a few feet for calch ruw of pecans in oreler to vive theme the better show. In other words, let the nearest row of the cultivated crop) be three or four feet frome the line of trees.

How to Transplant the Trees. - The pecall is a little more difficult to transplant and make live than many of the other frotit trees, and therefore very sereat precatition?

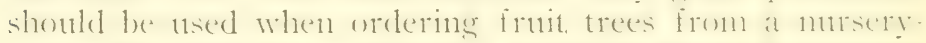

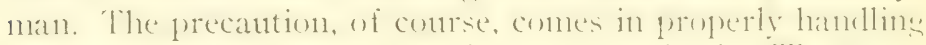
the erees inmediately atter they are recerved. The routs must not be allowed to dry onte, becatese it 1neans alnow sure death for the trees if this is allowed to take place. (1) contrse, the drying out of the routs of any frotit tree is rery bad for them, hut it is worse with the pecan that almost any other iruit or nut tree. 'Therefore, very great precalution must be taken in transplanting these trees, if one monld lu sure of having the larger percentase of them live after being transplanted.

In irleal soil for the pecan tree is a sandy loant with a clay subsoil, and, as said above, while it wants to le at fairly 
moist soil, ret it must be one that is well dramed. The clay sulbseil is not absolutely essential, but usually at soril with a clay subsoil proves ideal for the pecan tree.

\section{Varieties of Pecans.}

There are a great number of varieties if the hudded on grafted pecans, but we believe that for the average home urchard the planting may be very well reduced to fonr or tive, or six varietics. The king of all pecans is, heyond question, the sichley. It is not the largest, but the shell is very thin, hills out weth and the quality is tip top. Of all the varieties none has a better reputation than the Schles, and we think if one wishes to select only one variety in plant in the home orchard, then the schley should, undoubtedly, be the one ter select. It is a rather shy bearer, and if it were not for this reasun it is doubtful if all the other varietien put together would be planted as extensively as this one.

We think, therefore, that the Schley, Stuart, Success. Frotscher and Ian Deman are the leadine varieties of pecans for average conditions in the South.

We think om second choice of these varieties would be success. It is a large pecan with a very thin shell, and a high class nut in every respect. It is gaining in faror very rapidly with the pecan growers, and we believe the home orchardists would not make a mistake to plant at least at few of this particular variety.

The Stuart is another variety that produces a large nut. It is me of the most desirable varieties for conmercial furpeses. The nut is very large, and while the shell is not as thin as is the shell of the schley, yet it is thin enongh to crack with comparative ease.

The Frotscher is said to be the largest of any of the real paper shell pecans. It is a variety that always does hest in comparatively moist ground, and therefore its planting should be limited to bottom or semi-bottom land. 
The Van Deman is one of the old standhy varieties. The nut is long and the tip end of it cones out to a rather sharp point. The shell is easily craclied and the quality of the nut is good.

\section{Trees Require Thorough Cultivation.}

One other point that we wish to emphasize in this matter of growing pecans, and that is, to succeed with them, cultivation must be given. It is not enough to plant these trees and let the field around then grow up in weeds afterwards; becanse if this is done real success cannot be attained. In fact, if your are not soing to cultivate your trees it will be far better not to set them at all. If you don't grow crops in between the rows of pecan trees, cultivate the entire ground, and do it just as thomonghly and just as frequently as though some of the ammual erowing crops were being grown on that ground:

When to Cultivate. Cultivate throughout the spring and early summer, and then in late July sow cowpeas, or some other stmmmer lestume for the purpose of increasing the fertility of the soil. Of contrse, if one is growing cotton, or some other cultivated crops, in between the pecan tree rows, then the wround will be taken up with these, and the cowpeas or other summer lesumes camnot be planted at the time mentioned. If these cultivated crops that take up the soil for the entire summer are grown, then, in the early fall sow some of the winter leames, preferably crimson or bur clover.

Thorough Cultivation Brings Satisfactory Results. - Just as with any other orchard or annual crop, the returns will be detemined very larecly by the attention siven to the pecans. When une lets the trees "linock" for themselves, then the returns will be little, if anything. If they are given careful cultivation, fertilization, eic., then the returns will. under average conditions, be hishly satisfactory and profitable. 
Do Well Near Barns.-C ertainly everyone should plant

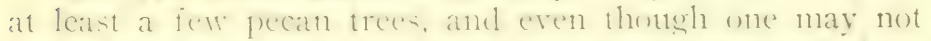

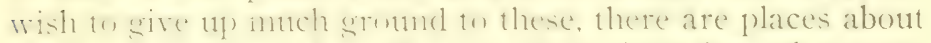

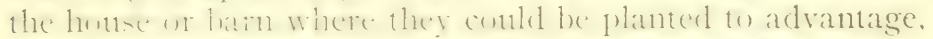
becanse they de remarkibly well when planted close to the

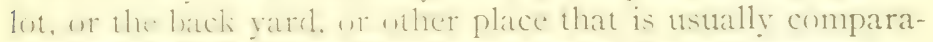
tively rich and moine. But keep in mind that wherever they are planted, thornele cultivation shonld be givene at least nutil the trec is several reats old and more able to "knock" for itself, so to speati, than when it is quite young. 


\section{CHAPTER XI.}

\section{FIOS GROM IIELI, IN COTTON BELT.}

Do Well Where Cotton Grows. - A few fig bushes should be in every home orchard, or at some place abuut the house: because there is no more delicious fruit grown than the fig. It is true that in a good many sections of the South the fig is killed quite frequently during the winter, but like the cat uf nine lives, it has the ability to come back and keep on coming back. We do not believe we have ever seen a fig bush killex down to such an extent that it would not come right lack irom the roots the following year: and even thoush it dexeset killed every now and then, it is well worth while to wrow them in almost any section where cotton can be enrown. It is altogether probable that cotton can be wrown sucessfully a little further North than can the fig: yet we have linown fig bushes to flourish in those sections that were considered well toward the northern part of the cotton belt.

Desirable For Preserving Purposes. Figs have heen wrown commercially only to a very linited extent in the Tinited States, except in California, and this is probably becaltse of the fact that in a fresh state the fruit does not ship rery well. Of conrse. figs are grown commercially and dried in California and other semi-arid sections of the fuited siates, but they have never heen gromen commercially to any great cetent and shipped as fresh fruit. And. as said aluse. this is laregely due to the fact that the frowt does not ship well. However, it is one of the very best fruits for canning and preserving purposes and for eating in the fresh state when it can he consumed right where it is errown. C) course, the figs can be marlieted locally; that is, on the marliets close enough by that the fruit can be sold the first day it is picked, or at least the following day.

Ve unhesitatingly say, therefore, that in practically all of the cotton belt everyone should have at least a few fig 


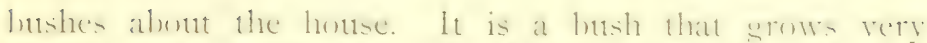
rapidly and rearlily and will often bear the second veat from setting.

Where to Plant Figs. I good plate of set lig bushes is in the hack yated in a more or less protected place. Lispecially in the neper pate of the south the lig husher shombl be planted on the south sicke of the huilding. or other plates that will give them nuse or less protection. Then, the tis. especially like at mesiat plater. They do mot like a soil that is water sogged. hut a rich, mosist soil: and some ui the wery finest fig hushes we hate ever acen were these at the

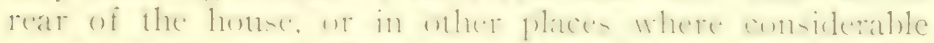
water was thrown. The corner of the sarden or near the lot, of ether place that in liable wh he quite rich and fairly moist, will be fomend an ideal place for the bushes.

1. atid above, the buthe are very ea-ily smown, and white they respomed readily to good tratment, sheh ats conl livation, femilization, etce yet if they are given a gomed rich. moist soil it matters little whether or nod thes are colltivaterl. Taken as a whole, thomehe they do respond quite realits as good treatment.

\section{VARIETIES OF Figs.}

Brown Turkey lery llardy. Sonte wif the varieties are mere hardy than others. The Prown Turkey is one of the most hardy varieties we have, and is well alapted to growing in the upper part of the Somth, an weil as in the heser part. The White Adriatic is another geond variets. hut shemld not he planted in the nuper part of the Sintelt, and account of it being lese hardy than some of the other bartedies. Masnolia and Bronswich are two varieties that do weell in the lower part of the South; that is, in Sonth Texas. South

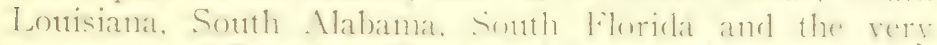
lower part of Georeia. They shomld not be planted wery far nom of Savamah, (jeorgia. Montwennery, Vlalbama, and Shreveport, Louisiana. 
Celestial Excellent Variety.-One of the very best varieties of figs is the Little Celestial. It is the smallest size, but very sweet, and possesses a quality very much superior to that of any other variety of figs known. It is an excellent canning and preserving variety as well as the king of all figs for eating purposes. It does not produce as big a yield as the larger varieties, of course, but it is a very prolific variety; and this fact makes up largely for anything it lacks in size.

Varieties for Different Sections.-To stum the whole matter up, our recommendation would be that everyone living well within the cotton belt should at least plant a few fig bushes for home consumption and for supplying the nearby local markets. Those living in the middle and upper parts of the South should plant, almost exclusively, the Brown Turkey and Celestial. In the lower part of the South, or in the Gulf Coast region, the above two varieties along with the White Adriatic and the Brunswick, should be depended upon largely. The Blue Genoa is another variety that has done quite well in the Gulf Coast section.

Put in Protected Place.-If the proper varieties, therefore, are planted in these different sections and attention is given in the way of putting the figs in a comparatively rich place and a semi-protected place, there would be no reason why figs cannot be grown successfully in the middle and upper parts of the South - at least. almost to the northern limit of the cotton growing section in the upper part of the South. If the simple directions given in this chapter are followed, then there is no reason why an abundance of figs for home and local markets cannot be grown in practically all sections of the South. 


\section{CHAP'TER XII.}

\section{PRUNING FRUIT TREES.}

Properly pruning fruit trees is a matter of very great importance, hecause neitler the largest amount of fruit, nor the best fruit, can be obtained without it. Of course, a large fruit tree can be produced without pruning, but the object is to ged, not so much a great big tree, but a well formed and a well balanced one that will produce an abundance of first-class fruit, and in order to do this, pruning must be practiced.

Prune Trees for 1 ood Production.-In the case of the peach, the fruit is borne on wood that grew the preceding year, and therefore the peach tree that does not produce a liberal supply of new wood cannot produce maximum crops. Pruning a tree in the winter time practically throws it into wood production. The more severely a tree is pruned during the winter the greater the effort put forth by that tree the following season to produce new wood. Therefore, in order to have enough wood to produce a good, crop of peaches each year, annual pruning that is more or less heavy must be resorted to.

Thus we see that pruning nutst be done, in the case of the peach, not only for the purpose of shaping the tree right, but in order to produce enough wood to grow a good crop.

\section{P'runing Trees So They Witl Not Grow High.}

Another thing to keep in mind is that a peach tree should not be high. A properly shaped peach tree should be so low and spreading as to enable one to stand on the ground and pick half to two-thirds of the peaches. You cannot lean a ladder against a peach tree to pick the fruit like you can the larger-growing and stiffer-limbed apple tree. 
IIow to Prune Apple Trees. - In the case of the apple tree, the pruning should not be so heavy, because the fruit is not produced on the new wood, that is, on the wood that stew the preceding year. However, the branches of the apple tree should be headed back when they grow quite rapidly. But the principal part of the pruning of the apple tree consists of heading back the branches that outgrow the average branches, and thimning out the branches and pruning so as to keep the tree properly shaped.

If three to five branches were not selected and left on the stump when the tree was headed back immediately after setting, this should be done the following winter. It should be done before any pruning is resorted to. One should pick out the three to five best branches on the tree, keeping in mind that they must be properly distributed around the tree and not exactly opposite each other, as explained in a preceding chapter.

\section{Selecting the Main Branches.}

Remove Branches From Main Trunk of Tree.-It matters not how many branches may start out the first season, all shonk be removed-that is, all that come from the main trumli of the tree-except the three to five that are selected (1) form the main trunk system of the tree. Then these three to five that are selected should be headed back rather sererely. In the case of the peach, they should be headed back from onc-half to two-thirds, depending on the amount of growth and other conditions. In the case of the apple, the heading back should not be quite so severe, but say from one-fourth to one-third, or where very rapid growth has taken place, about one-half

When these main branches are headed back, leave two or three side branches for each one of these main branches, selecting these in such way as to have them properly distributed and not coming too close to the others. One of the principles of pruning that should be kept in mind is, never 
let any two branches tonch or be close enough to each other to serionsly interiore with the proper development of either one. If this principle is liepte in mind, then wne can do good proning provided a few of the oflue principal promine facts are in one's mind.

Sunlight Is Reciuired to Color the Fruit.- Liach year when new bratules are allowed to develop from the branches that were headed hack the preceding year. only at fell should be left. If one allows all the hranches to develop, the result will be an abmelinte wi woud and at tree st thick that stulight cannos enter in and properly color the frutit. Therefore, do nut be afrated th thin ont brancles. leeeping in mind that what is wanted is an epen-headed frutit tree and one sufficiently thinnerl so the sminlight can get in throngh the top of the tree at lean for a short tine each daty. This is absolutely necessary in wreler to property color the imit. Fint camber ripen and take on its natmat colom with the total absence of sunshine.

\section{Common Sense Best Rule For Pruning.}

Branches Should Be Cut Just thove Good live Bud.... It is impossible $t$, give all the minute detatis of properly proninge a tree, but we believe that he following the matin

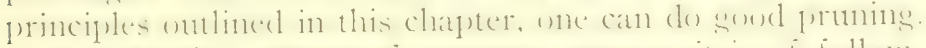
It is as much a matere of commonom semee as it is of follow-

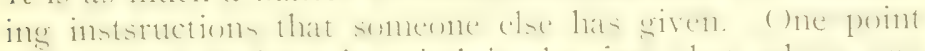
that should be hept in mind is the fate that where one

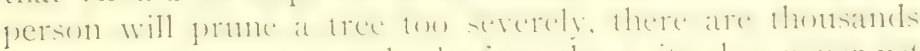
that will net prome (mough. In face, the writer hats never yet

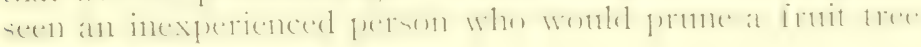
too severely.

tuother penint that should be hept in mind in proming is that when any branch is headed back, it should he cont off just abowe at ened live bud. [Thless this is done, that portion of the woud above the last bued will rot and posibily canse the decay of that whole branch later on. When 
making these cuts, they should be made slanting and not straight across. This may sound like a small point, but it is certainly an important one.

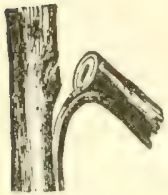

Fig. 1

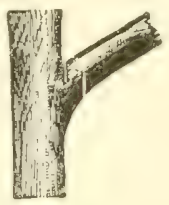

Fig. 2

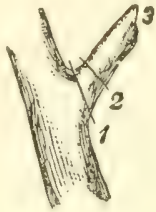

Fig. 3

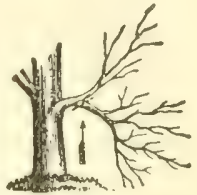

Fig. 4

RIGHT AND WRONG WAYS OF PRUNING.

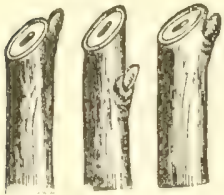

Figs. 5

Figure 1 shows how not to cut off a branch. By sawing a little on under side of branch as shown in Figure 2 , this splitting can easily be avoided. Figure 3 shows where a branch should and should not be cut. If cut at 3 , a stub is left that will probably result in decaying of the tree. The cut at 2 is too far away from the main trunk. The proper place to make the cut is shown at 1 . Figure 4 shows how and where to remove a side branch. Cut at the dotted line to which the arrow is pointing.

7 Always cut right close up to the trunk of the tree or the branch from which the limb comes. Figure 5 shows where a cut has been made too close to a bud so that the bud is injured and will seldom produce fruit. In figure 6 the cut was made too far above the bud; in figure 7 , it was made right.

Cut Branches Smoothly to Prevent Rot.-Another point that should be kept in mind in pruning is, that when a branch is cut off entirely, that is, when it is cut off up next to the branch from which it came, or from the main trunk of the tree, the cutting should be done right up smoothly with the trumk of the tree or the branch from which it came. If a stub is left, even though it may be only onehalf inch or one quarter inch in length, trouble is liable to result. This stul) cannot get food and dies and rots, and when it rots. it rots right on in through the branch, or the main trunk of the tree from which it came, and this often means "the beginning of the end" of that tree. One has often se'n hollow trees where the direct canse of it was the cutting off of a branch without cutting it smoothly with the trunk of the tree, but leaving a stub. It is highly important that this point be kept in mind and absolutely lived up to, because if it isn't, it will be sure to cause trouble. 


\section{Proper Way of Cutting Large Branches.}

When a branch larger than three-quarters of an inch in diameter is cut uff, the wounds should be painted with some kind of paint. This is desirable becatse the painting of the wound will prevent the rot from getting to work on the tissues of the wood. If this painting is not done, rotting may start. It is just like covering a wound on your own flesh. It is necessary to cover it over in order to give the living tissues at chance to heal the wound before a fungous disease gets busy on the outside.

Remove All Diseased Branches. The proper tince to do this prtninge, of course, is in the winter, or after all the leaves have sleed from the trees and they have hecome thoroughly dormant. P'runing shoted be done every winter. The younger the tree, the more fruning required as a rule. The peach tree, as said above, will require more pruning than the apple tree. Cherry trees do not require very heavy pruning. Fig bushes require only thinning out and heading back wherever necessary in order to keep them in the desired shape.

When pruning fruit trees during winter, every diseased. dying or injured branch shonld be taken ont, because every time one of these is left, it increases just that nuch the chances of the whole tree becoming diseased. It is not necessary, or even desirable. to wait until winter to remove such branches as these. It is a mighty good plan to watch the trees carefully, and every month or so remose any diseased, dead or dying branches that cannot possibly be any sond to the trees in the future. Remove these at any time they are found.

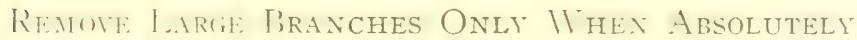 NECESSARY.}

It should be kept in mind that the proper way to prune at fruit tree is to so prune it that large branches will never have to be removed. Of course, if the hranches are allowed 
to become too thick, it is better to remove a large one than to allow too many of them to remain. But the point that we are trying to make is, that if the proper pruning is done from the beginning, it will never be necessary to remove large branches. It is always disturbing to a tree more or less to remove a great big branch, and this sh nild not he done except where it is absolutely necessary.

Saw Off Large Branches to Prevent Splitting. - One other point with reference to pruning is that when a large branch is cut off, be sure to cut it in such a way as not toallow it to split off. Saw it off three or four inches from the trunk of the tree, making a small cut on the monder side (o) prevent splitting, and then afterward saw off the stub right up next to the tree. liy going at it this way, splitting can be avoided.

As said above, in pruning a fruit tree, one must use his own common sense and good judgment as much as anything else. It is well enough to have in mind the principles of pruning as outlined by others, but this is about all that can be done. Follow your own common sense in the natter. 


\section{CHAPTER XIII.}

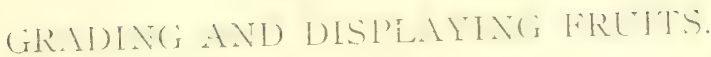

Believing that every farm bome where there is a home orchard should marliet the surplus fruits on the lecal matlet, we are discussing in this chapter in a very olenentary way, sone of the best methoxis of picking, grading. packing and displaying fruit so as to hring good prices.

Proper Marketing Brings Maximum Prices.-In the marketing of fruits there is just as much in properly grad-

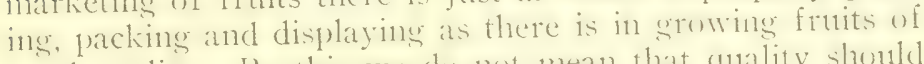
worod quality. By this we (1) not mean that quality shombl fie sacrificed, becatrice that is the fomblation of the whole proposition, and muless there is quality the highest prices cannot be obtanded. It is equally true that muless frotit is properly parded. packed and displated, the naximum prices cannot he ohtained. So this is a two-sided proposition: that is, the work is not completed when the fromit is grown and the quality is good. It must be properly wathered, graded, packed and displayed. It might just as well be accepted as a fact that those who refuse to give real consideration, thonght and care to this matter of srading. packing, and displaying the fruit, cannot secure maximmml prices.

Display Fruit in Atractive Form.-In order to secure these maximntm prices, the fruit nust be displayed in attractive packidges. It doesn't matter how goud the quality is, if one puts apples, peaches and othere fruits in an old sacli ot in an old tambloled-down box, naximum prices will not he received. What one needs to do is to lieep on hand a sufficient numuler of various kinds of packayes to properly market the fruit in an attractive form.

IIe have very often known it to happen, where fruit of equal quality was carried to marliet, one lot in attractive packages and another in a slip-shod manner. that that properly put up brought two or three times as much as the sante fruit that was not properly displayed. 


\section{Supply local Markets With Fruits.}

Market Fruit in Proper Craest, Baskets, Etc.-We believe that every farmer should have a home orchard, sufficiently large to supply all the home needs, and to supply. in a limited way, the home marliet. Ne venture to make the assertion that there are not many farms from which the surplus fruit could not be marketed to advantage and without in any way diminishing the supply needed at home.

Therefore, every person who has any of this fruit to market in the fresh form, should supply himself with the proper crates, baskets, etc., needed for handling and displaying this fresh produce in the best possible manner. With this thought in mind, we present a few illustrations of some of the common types of containers used for displaying and marketing various kinds of fruits.

\section{Detaled Description of Several Marketing Con-}

\section{TAINERS.}

No. 1 is the ordinary grape basket, made for shipping grapes. As is shown, this basket is made with a solid board bottom and with veneer sides and also a veneer cover. This cover is fastened on with little wire hooks. This type of basket can be used when marketing various kinds of fruits. but is especially made for the marketing of grapes, and certainly everyone having even a small quantity of grapes to market should have on hand a number of these baskets.

No. 2 is what is known as a display basket. This is a basket which everyone who markets any fruits should have a supply of, because it is long and shallow and is especially adapted to displaying fruits to the best advantage. It is suital)le for displaying peaches, apples, plums, pears, or in fact, anything of this kind that one wishes to show off to advantage. As said above, no one marketing fresh fruits in a local way should be without a supply of these baskets.

No 3 is what is known as a repacking basket, and can be used for marketing fruits, or can be used for putting fruits in crates. This is the size of basket that is ordinarily used 
in four and six-basket carriers or crates, and is very well adapted for this kind of work. One can very easily display a basket of this kind with peaches, apples. plums, pears, cherries or anything of the lind. They are comparatively inexpensive and can be had in one, two, three, or fourquart sizes.

No. 4 is a picking stand or carrier, and everyone growing berries, particularly straberries, raspherries, dewherries, etc., should have a supply of these, because the quart berry haskets fit into them nicely, and one can carry a considerably greater number of baskets of berries this way than can possibly be carried by any other method. They can he had in different sizes and we believe the two main sizes are those that carry four of the quart baskets and those that carry six of the quart baskets. The quart berry baskets that are ased for packing strawberries, dewherries, etc., are the kind of haskets referred to in this paragraph. Those who have tried to handle strawberrics, dewherries, raspberries. cte., withont making use of this carrier, have missed sonething. Certainly a supply of them should be had hy all berry growers.

No. 5 is what is known as the shipper's bushel basket. The cover on top is what is known as the hoop cover and is nsed by a great many growers and shippers of various kinds of fruits and produce. The lid is slatted as can be seen from the illustration. This is a very popular kind of container for marketing various kinds of heavy fruits and regetables, such as apples, peaches, pears, etc. All of those catering to local markets with fruits should certainly have on hand a supply of these.

No. 6 is that kind of a star'e basket which is mighty handy when picking fruit. The bail on the hasket swings or drops down, thus making it easy to handle. The bail is attached to the basket by rivets and washers, which make it strong and durable. This basket is quite useful on any fruit farm, because it can be used, not only for picking fruits, but for a great variety of purposes. 
No. 7 is that of a four-basket carrier. This carrier is nseful when one wishes to properly handle or display small fruits, such as dewberries, raspberries, strawberrics, etc., in larger quantities than a single basket. And then, too, this carrier makes it more convenient to handle several baskets than if they were handled singly.

No. 8 shows a crate which comes in two sizes, namely. 16 and 24 quarts. This is the crate that is especially adapted to the marlieting of strawberries or other small friuts of this kind. The baskets containing the fruit are packed right in on top of each other and then the corer is nailed on. Even though marlieting strawberries, dewberries, raspberries, etc., un a comparatively small scale, one vill find the use of this crate quite desirable.
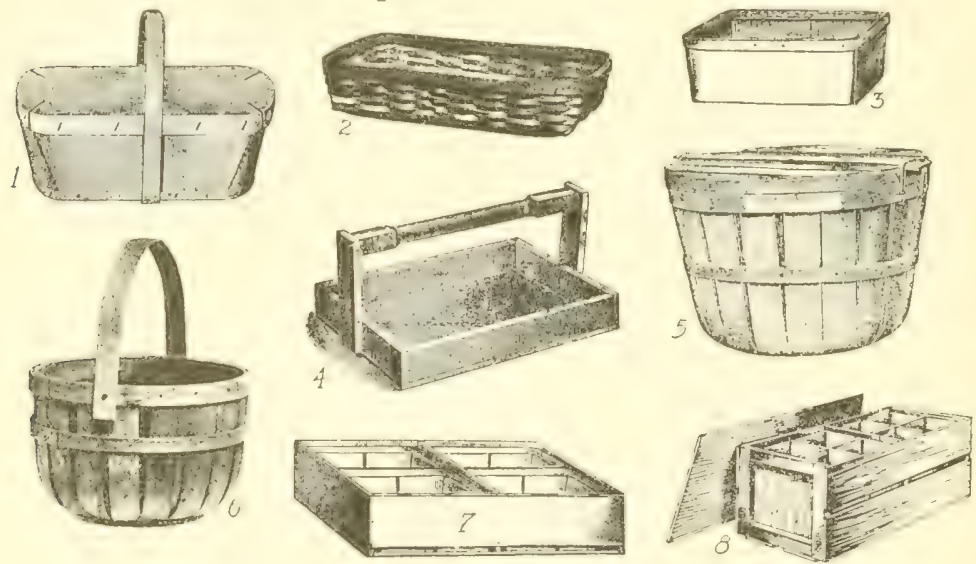

Different Types of Fruit Containers

Many Dollars Can Be Saved By Marketing Fruits.

There are many dollars worth of fruits going to waste on practically every. Southern farm. It is counlly true that while this very thing is taking place there are follis in the cities that do not consume anything like the quantity they should. It is true that this may sometimes be because fruits 
are not bringing a good price, but we venture to make the assertion that if one will supply himself with the containers similar to those shown above, and will grow tirst-class fruits, pick, wade, pack and display them properly, satisfactory prices will be received.

When to rick Peaches. - In picking peaches fo sell ntr the local market, one shomld be properly informed as to when such peaches shomld be picked. It will not do to wait until they get soft and then pick then ; hecause ('ven though they may not be carried more than a mile or two and mav be marlieted at once, if they are soft when they are piched they will invariably be in had shape before they are marketerl. Therefore, the propere thing to do is pick then just before they get soft. I) wot pick them wntil they are wedl colored and just rearly to become soft. Inyone who will carefully examine the peaches a few times ean very well tell when a peach is just about ready to become soft.

In picking the peaches, be careful not to bruise theme: also, dont snatch them off as theneh they were rocks, hret take hold of the peach and twist it and it will hreak otf in such way as not to injure the peach or the hranch from which it was picked.

In picking apples, pears, of other fruit of this hind for the lecal marliet, it is equally important to wather them before they become soft. One can, with a little experience. tell when the fruit is just about to ret soft and pick it two to three days before this time.

Pick Fruit at Proper Time to Get Best Results.-- Ile late seen many perple make the serions error of imagining that the peaches, plums, pears, or apples should not be picked until they are thoroughly soft or in the condition which one would like to have them when pulling from the tree to eat at once. This is a mistake. Anticipate the ripening period by twe or three days, when they are to be put on the lecal marliet, and they will be pickes at the proper time in order to secure the best results. 


\section{CHAPTER XIV.}

\section{VARIETIES OF FRLIT THAT SHOLTIS SUCCEED IN THE SOUTH.}

Varieties Recomalended for the Upper South.

Apples :

Early I'arictics-Yellow Transparent, Red June, Early Harvest, Horse, Maiden Blush, Wealthy.

Mid-Season-Kinnard, Bonum, Grimes, Delicious.

I'inter-York Imperial, White Pippin, Rome Beauty, Royal Limbertwig, Winesap, Stayman Winesap.

Pears :

Keiffer, Seckel and Bartlett.

Peaches:

Named in urder of ripening: Mayflower, Greensboro, Arp Beauty, Carman, Ililey, Belle of Georgia, Elherta, Late Crawford, Chairs, Smock, Salway.

\section{Plums :}

Native Varieties-America, Munson, Wild Goose.

European l"aricties-Green Gage, Purple Damson, Shropshire Damson.

Japanese Varietics-Red June, Burbank, Abundance.

Cherries:

Sour l'arieties-English Morello, Montmorency, Richmond.

Swect Varieties-Tartarian, Windsor, Spanish.

Raspberries:

Black Variety-Cumberland.

Red Variety-Cuthbert.

Yellow Variety-Golden Queen.

Purple Variety-Columbian.

Blackberries :

Early Harvest', Eldorado.

Dewberries

Lucretia.

Grapes:

White Variety-White Niagara.

Red Varicty-Brighton, Delaware, Lutie, Catawba.

Black Variety-Concord, Moore, Worden and Ives.

Quince:

Angers, Champion, Meech, Orange. 
Varietiles of Fruit Reccommended For the Mindle South.

Apples :

Early l'arictics-Red Aotrachan, Horse. Yellow Transparent, Red June, Early Harvest, Bledsoe, May (very early), Williams.

lid-Siason-Bonum, Kinnard, Delicious, Grimes, Virginia Beauty.

I'inter-Winesap, Yates, Terry, Jonathan, Stayman Winesap, York Imperial.

Pears:

Keiffer, Early Harvest, Leconte, Seckel.

Peaches :

Early to late summer and even into the fall in order of ripening-Mayflower, Sneed, Greensboro, Red Bird, Carman, Hiley, Belle of Genrgia, Eillertat, Late Crawford, Munson Free, Eaton's Gold, Salway, Stinson and Gladstone.

\section{Plums :}

The same varieties as planted in the upper South should be used.

\section{Cherries:}

Only son varietics should te planted: Enelish Morello, May Duke, Richmond, Montmorency and Baldwin.

Raspberries :

Cumberland, Gregg (both lilack): Cuthluert, St. Regis (both red).

Blackberries:

Early Harvest, Eldorado, Wilson.

\section{Dewberries:}

Lucretia.

\section{White Grapes :}

Niagara, Diamond.

Red Grapes:

Lutie, Agawam, Catawba, Brighton, Delaware.

Black Grapes:

Concerd, Camman, Munre's Early, Campbell's Farly and Worden.

Persimmons :

Japanese. 
Figs :

Brown Turkey, Celeste and Ischia.

Scuppernong Grapes :

Scuppernong, Thomas (reddish purple), Black Misch, James, Flowers, Eden and Memory.

Mulberries :

There should be planted for the hogs and chickens, but ripening quite early in season are not distasteful to eat; Hick's Everbearing, Black English and Browning.

Pecans :

1)elmas, Irotscher, Money-Maker, Schley, Stuart, Van Demanfor the lower part of the middle South. Indiana and Mantura-for the upper part of the middle South.

Pomegranate :

The pomegranate can be grown in the lower part of the middle South.

Quinces:

Angers, Champion, Meech and Orange.

Varilities of fruit Recommended for the Lower SOUTH:

Apples:

For the lower South, apples do not do well as a rule. How(ver, the following varieties will be the best to depend on: Horse, Early Harvest, Red June, Yellow Transparent, Kinnard, Terry and Fanny.

Pears :

Keiffer, Le Conte, Garber.

Peaches:

Florida Ciem, Honey, Jewel, Waldo, Angel. Imperial, Pollas. (limax, Japan Dwarf, Colon, Cobbler, Onderdonk, Estelle, Hall Yellow, Dorothy.

Cherries:

Will not grow satisfactorily in the lower South.

Persimmons :

Japanese persimmons are at home, of course, in this section. The most largely planted varieties: Tanenashi, Eureka (hardy variety), Zengi (carly variety). Castata and Ormond are late varieties. 


\section{Figs:}

Celeste, Brown Turkey, Brmansick, Irchia, Magmolial, Lemon. Magnolia is grown very little except in sontluern Texas. but is the leading variety of that section.

\section{Grapes:}

White Grapes-Wapanuka, Krause, Niagara, Hidalgo.

Red V ariety-Brighton, Valhallah, Captivator, Agawam.

Black Variety-Carman, Cloeta, Champenel and R. W. Munson.

\section{Scuppernongs :}

Raspberries:

Dewberries:

Blackberries

Mulberries:

All varieties suitable for the middle South will prove satisfactory in the lower South.

\section{Pecans :}

Well known varieties like Delmas, Frotscher, Money-Maker, Schley, Stuart, Van Deman.

Walnut :

In both sections of the lower South the English walnut can be planted to a limited extent.

\section{Orange :}

The satsuma orange will do well in the upper part of the lower Sonth. It grows well in the vicinity around Mobile, in

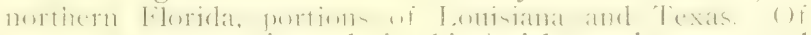
course, no attempt is made in this article to give a general list of the citrus fruits that are suitable for the lower South.

No effort has been made to name all of the different varieties that will do well in the different sections of the

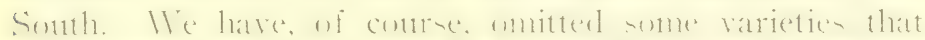

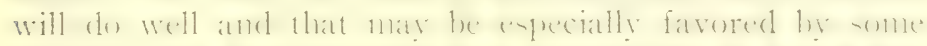

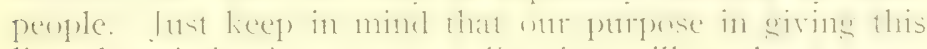

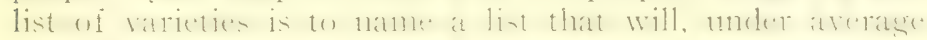
conditions. prowe satisfactery in the sectien for which they are named. 


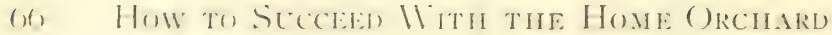

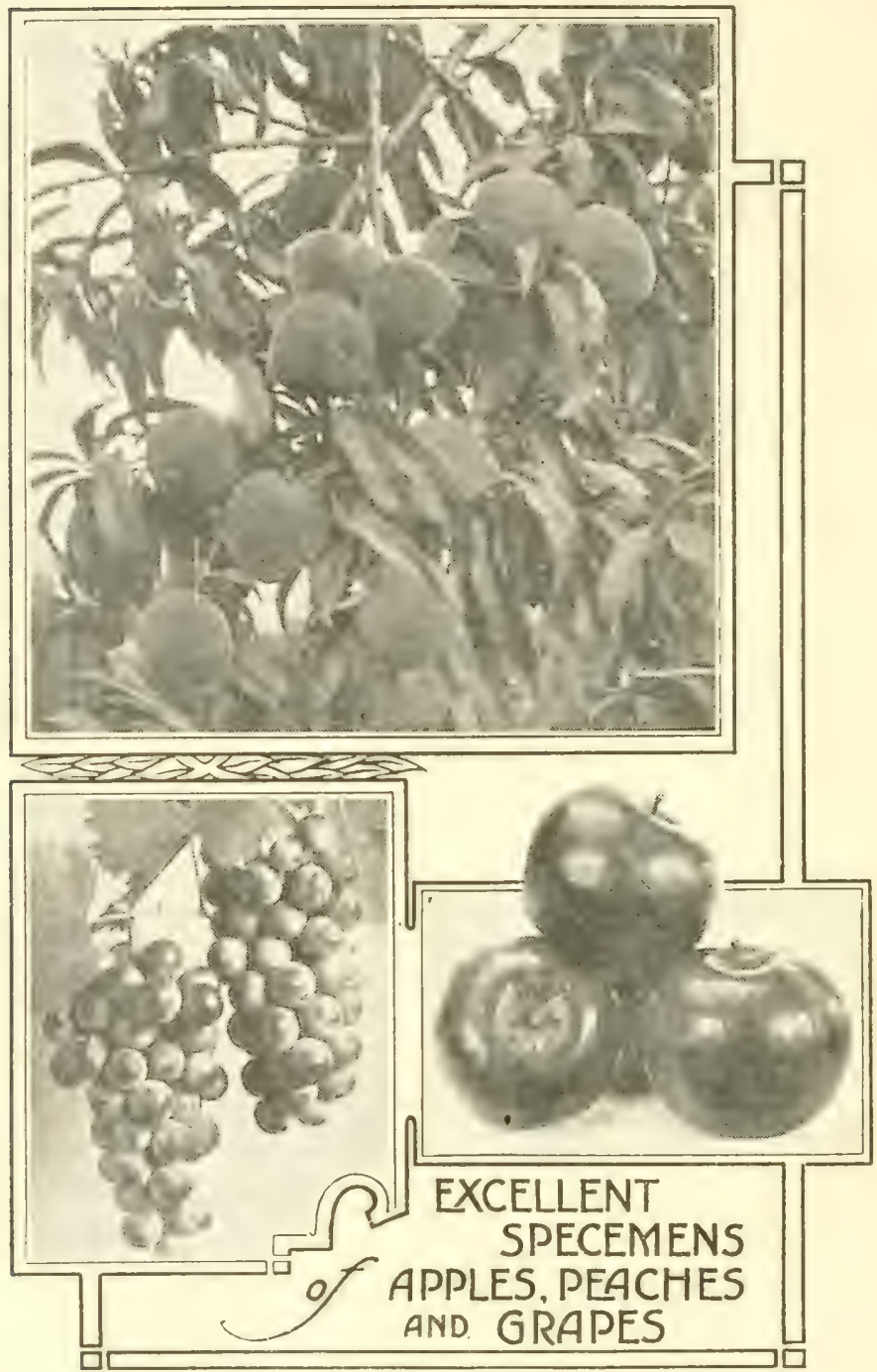




\section{CHAPTER XV.}

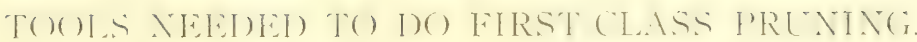

Don't Use Carpenter's Saw. - No wne can werm the hest fruit, or even satisfactory fruit, muless the trees are properly promed. No one can do the right kind of pruning without having the propere touls for doing the work. The have -een many trees butchered by persons attempting to prune with an ordinary carpenter's saw and axe.

Four Different Tools Are Needed. - II here only a few fruit trees are wrown in the home orchard, at least four different touls are needed and these are as follows: (1) pruming linife, (2) hand pruming shears, (3) pruming saw. (4) a pair of long-handled pruning shears.

Pruning Knife Needed. .. () ne can, of conrse, do withont the pruning linife, hut this is not desirable, lecatere often neither the long-handled nor the hand proning sheats. nor pruming satw will (h) the work wnder certatin comclitions yute so well as a pruning knife. Neither will an ordinary pocket knife do the work so well, becanse a pruning knife has what is commonly known as a hooked bill. This is nothing more nor less than a knife with the blade curving inward so as to sive the principal cutting power to the blade neat the end.

\section{Long-Handled Sijears Give Much Power.}

Hand Shears Essential.--The lons-liandled pruning shears, which are also illustrated alome with this chapter. are highly desirable, because hy using two hands, and hy nueans of these long handles, great cutting power can he secured. The hand pruning shears, illustrated in this chapter. are the ones with which most of the pruning should be done, but the long-handled ones will be needed on practically crery tree. Therefore, be sure to wet these and do not try to do the work with the small hand shears entirely.

Shape of Saw. - The pruning saw illustrated along with this chapter is of the proper shape. Notice that the blade is narrow and curved. It is curved in such manter as to 
make cutting as easy as possible. Under no condition should me try to use an ordinary carpenter's saw, because this is
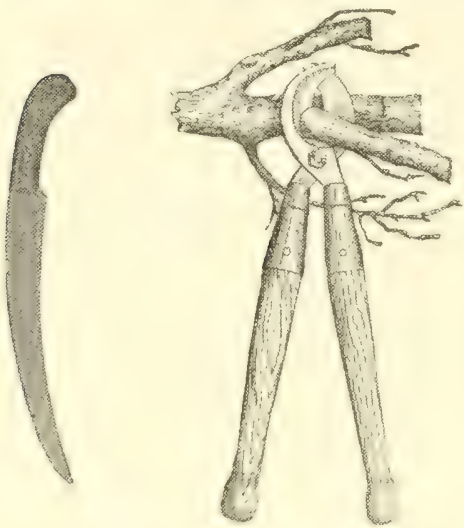

The Right Shaped Pruning Saw
Long-handled Pruning Shears
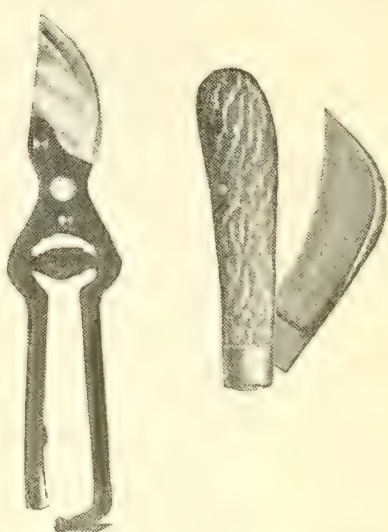

Hand Pruning Pruning Knife Shears

so wide as to make it imposiblele to saw off the branches without knocking the bark off the tree in many places. The saw shown herewith, or even a straight saw with a narow hade. shomld alwaty be used in preference to the orelinary wide carpenter's saw.

Cost of Tools...-The purpuse of this chatpter is iont to attempt to tell how to prome fruit aress, but to poime ant reatctly what we neede he fore tirst-class proning can be dome. Just malie mp your mind once for all that muless at leas these four tools are on hand, first-class pruning is next to inmpossible.

The cost of these font toxls will vary from s\$t.00 up, depending on the puality. Is a rule, howerer, me cath

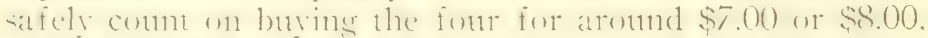

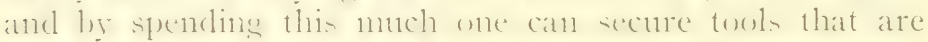

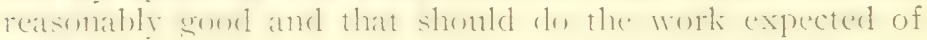
them. 


\section{CHAPTER XVI.}

\section{WINTER SPRAYING OF FRUIT TREES.}

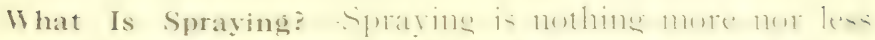

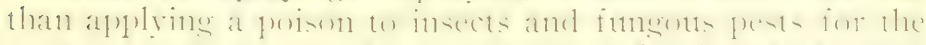

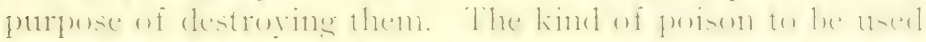

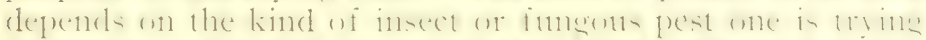

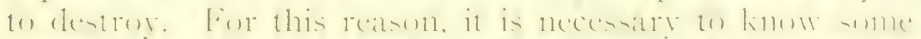

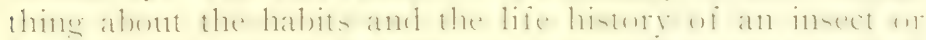

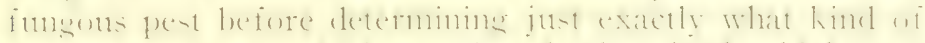

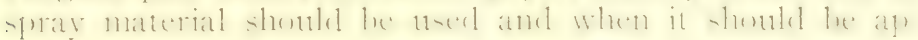
plied.

Two kinds of sprasing. In 1 le , ir-l place. spravine can be divided into two seneral divisions: (1) winter

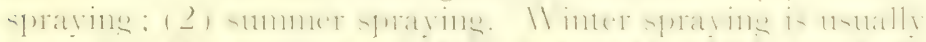

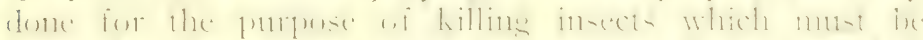

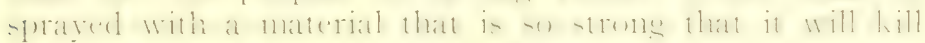
them just by coming in contact with them.

How to Spray for san Jose scale. I infer thi- heral comes one of the most desctructive and one of the most

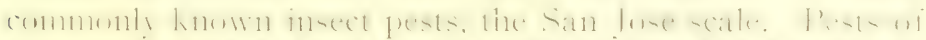

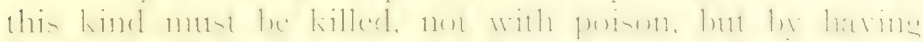

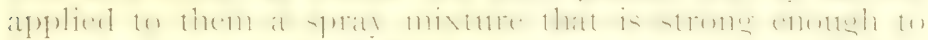

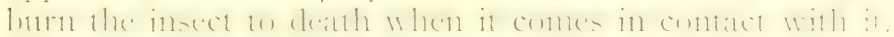

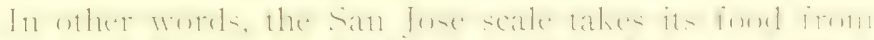

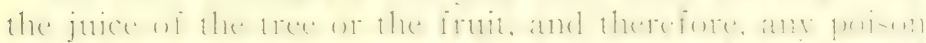

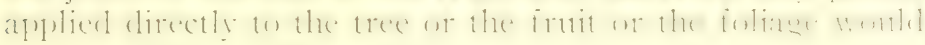
have no effect on this pest.

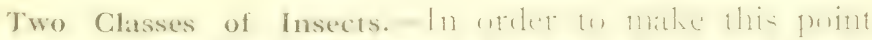

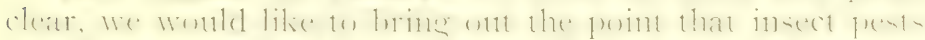

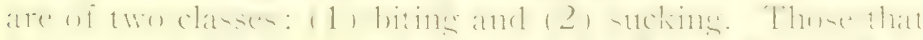

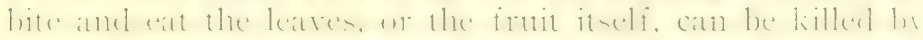

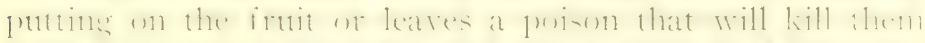

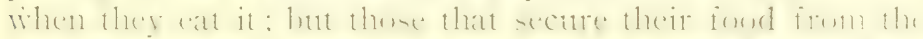

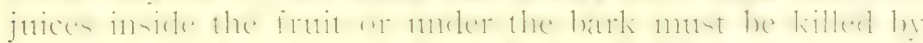

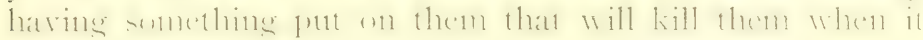
comes in contact with them. 


\section{San Jose Scale Scourge of Fruit Trees.}

Scale Worst of All Pests. - It must be kept in mind that this terrible pest, San Jose scale, probably causes the death wi more fruit trees than all other fungous discases and insect pest-combined. It is a regtular scourge to fruit trees. fitcrally thousands and hundreds of thousands of fruit trees die every year from the damase caused by this pest.

How to Detect San Jose Scale. The presence of San Jose scale on the fruit trees can msually be detected by carefully examining the bark. If it is covered or even speckled with an ashy gray substance that appears to be little round gray spots, the chances are that this pest is present. by rubbing the linife blade rather hard orer the place where one thinks the scale is present in large numhers, at yellowish substance may exude. This is a pretty conclusive proof that this pest is present. Keep in mind that the San fose scale is a little insect, yellow in color, living directly under a thin shell or scale. The shell or scale is aratish in colot, lout the insect proper is yellow.

\section{Spray For Scale Only During Winter.}

Now, lecep in mind that the only tinne one can put a spray on the iruit trees strong enough to kill the scale is during the winter. This is because of the fact that anything put on earlier, or while the fruit trees are growing. would be strong enough to damage the trees. The homemade line sulphur solution or the concentrated lime sulphur solution may be used.

Use Commercial Solution for Scale. - Is a rule, however, it is more desirable to depend on the commercially prepared solution than it is to make it at home. Both of these can be secured from advertisers in farm papers, and these advertisers have distributors and dealers in these materials nearly all over the country.

If for any reason anyone prefers to make the limesulphur wasli at home. directions for doing so can be 

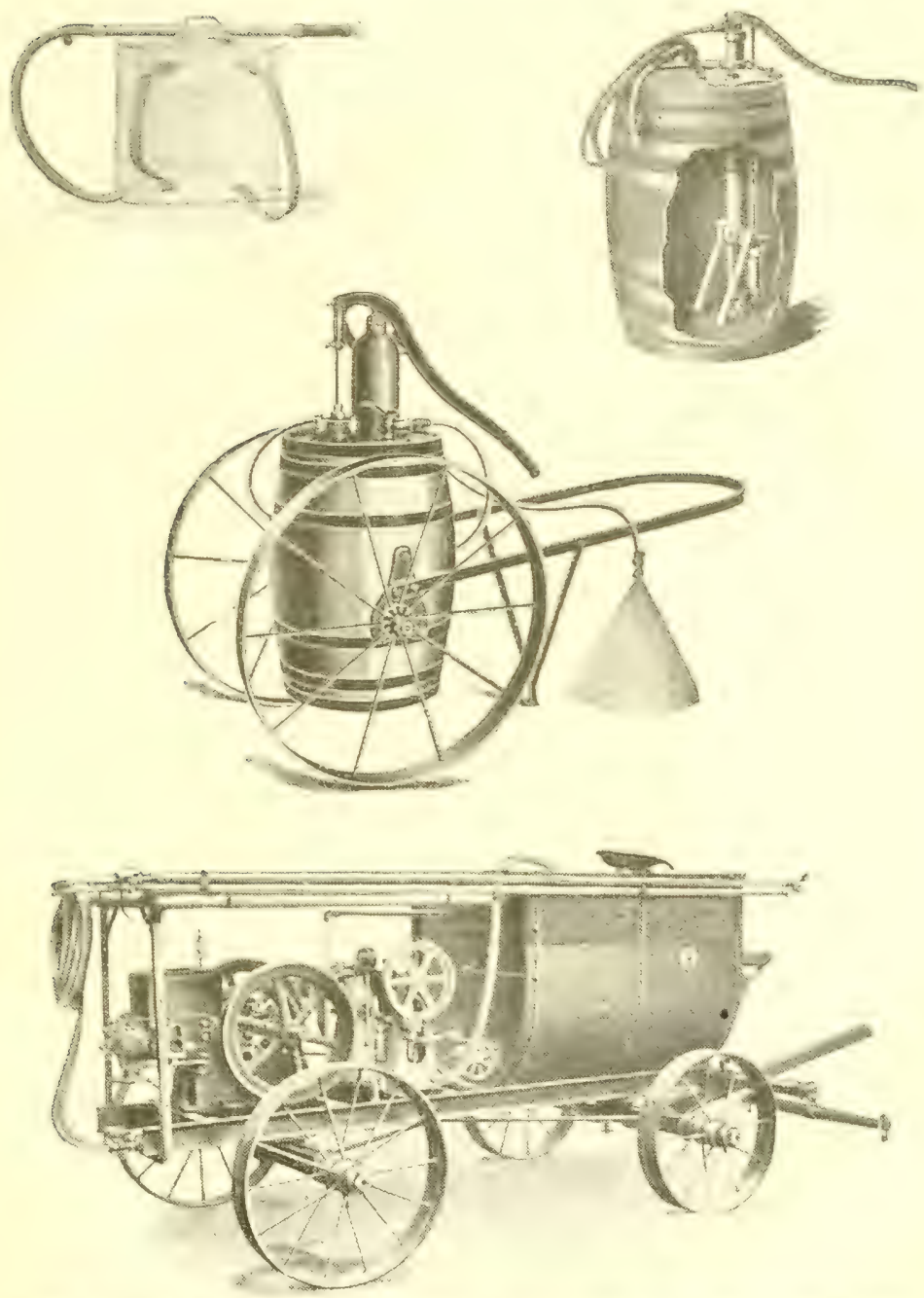

Upper left is a knapsack spray pump. Upper right and center. barrel spray pumps, and at bottom, a power spray pump. 
secured cither from your state agricultural college, your county agent or your farm paper. ITe would recommend, however, except where one is especially equipped for making this material, that the commercially prepared solution be nsed; becanse ont experience has been that, taking all things inte consideration. the commercially prepared solution is either cheaper or proves more satisfactory in the long run.

\section{Spray After Pruning Is Done.}

Destroy Praned Off Branches. The splaying. probably, shendel he done after the winter pruning has been done.

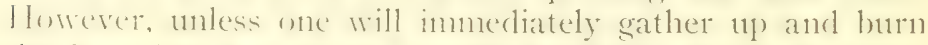
the hranches and twige cut wif the apple, peach or other trees, it is fat better to let them remain on the trees unt after the sprating. becatse if branches or twiss infested with sall fose scale are cut and left lying around sn the sornund, or in the edere of the orchard, these will serve as resular buecling patches for next year. Spraying is less fromble and tales lens worls and less spray material when proning is done before the winter spratying is given, and we recommend that the pronims be done first and then the

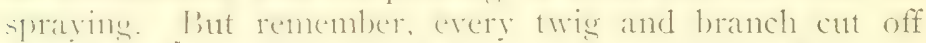
sumbl he linned in order to arod any possibilitiy uf having the orchated re-infested with pests from these proned of branches.

\section{Keie $\cdot$ Spray Solution Thoroughly Stirred.}

Agitator Must Be Kept Working. - Tim much attention cannw be wiven to this matter of seeing that the agitator in the hatrel or tank is in gond shape at all times becanse if for any reason this should break or not worle well, it neans that the spray misture will not be thoromehly nixed. and that fant of the tine fon will he spraying with a mixture that is too stroms. and at other times you will be spraying with nearly pure water. 


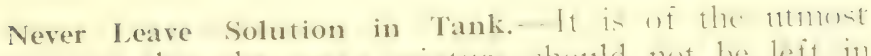
importanes that the spray mixture should mot be leit in

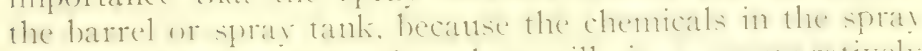

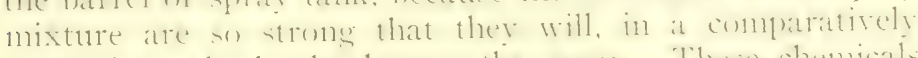

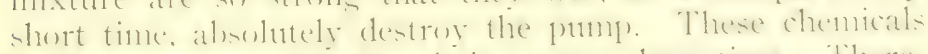
will eat it ont and destros it in a very short time. There

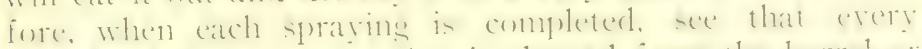

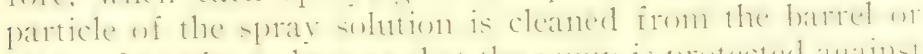

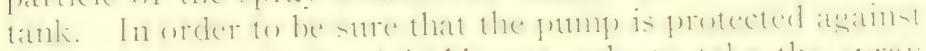

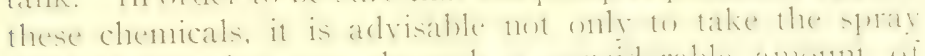

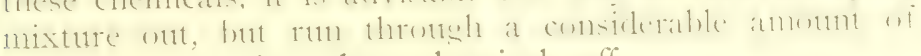
water so as to rinse these chemicals off.

Wear old clothes While spraying. In loing llid - flril!

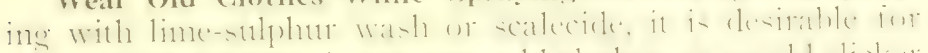

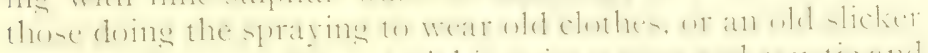

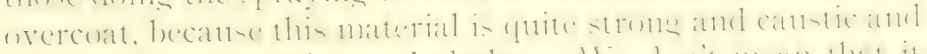

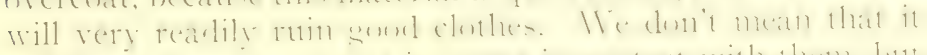

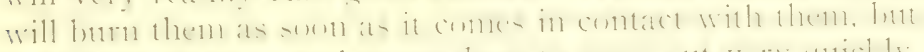

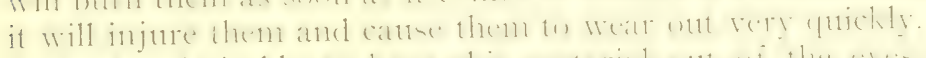

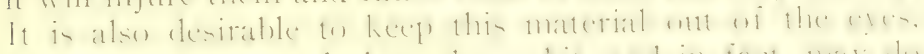

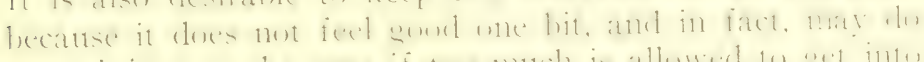

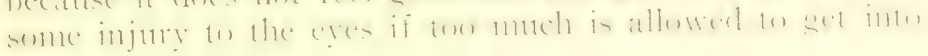
them.

Give Second Spraying Before Buds Sivell. Mllere tin

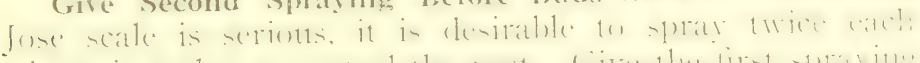

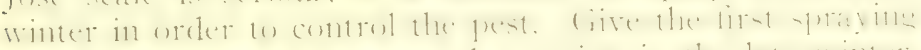

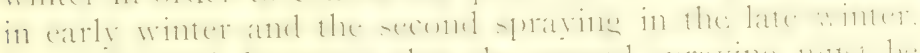

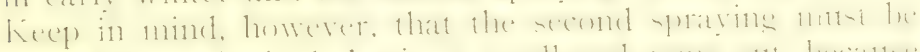

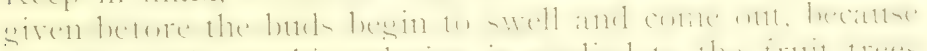

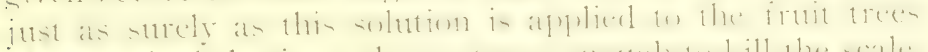

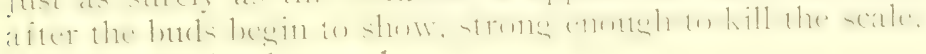
the tree will be damaged.

\section{SPRAYING a GoOd Fordi of Insurance.}

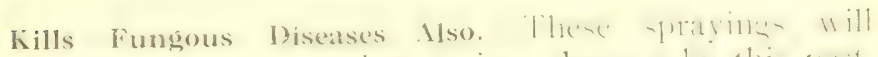

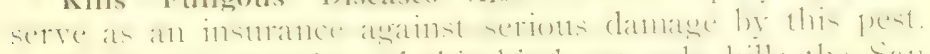

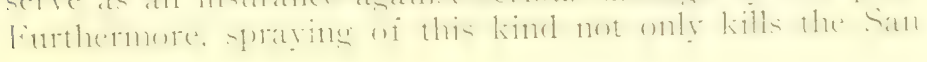


Jose and other scale insects that may be present, but destross literally thousands of fungons disease spores, such as black rot, brown rot, etc., that may have given trouble the past smmmer. Keep in mind that these plant diseases gor through the winter in the spore form and that ordinatry winter weather does not kill the spores. I However, it has been thoroughly demonstrated that this lime-sulphur or scalecide wash that is used for San Jose scale destsroys large numbers of these plant disease spores.

If in Doubt, Spray.-Therefore, even if you think you have no scale, which we very much doubt to be the case, it will still be a good idea to go ahead and spray. Ion can rest assured that you will be taking out a good form of insurance against the scale and that you will do enough gowd in the way of killing plant disease spores to make the spraying worth while from the dollars-and-cents standpoint. 


\section{CHAPTER XVII.}

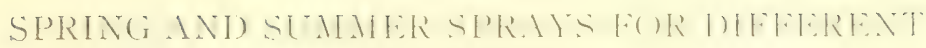
FRUTTS.

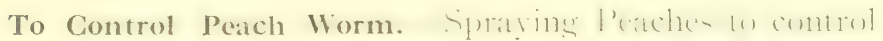

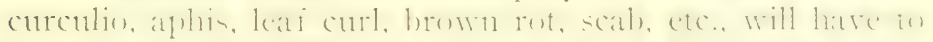

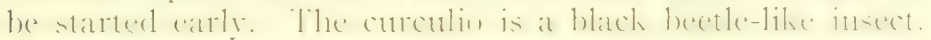

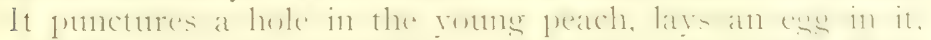

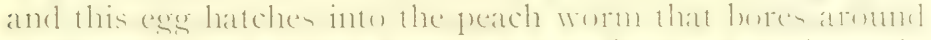

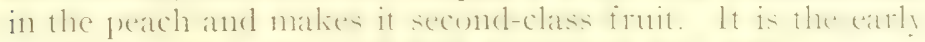
spring spralyes that will help to control this pest.

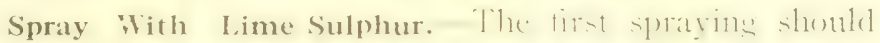

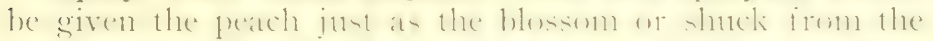

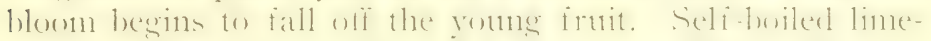

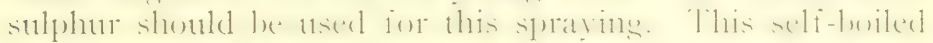

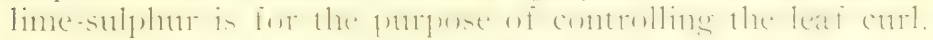
brown rot and scab. To control the curculio or worm.

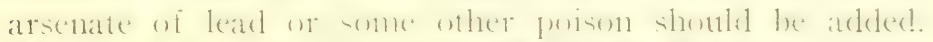

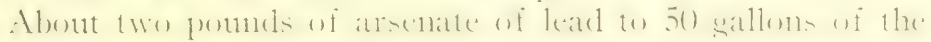
spray mixture is about the right quantity.

Second and Third sprayings. - Ti, properly (amterl worms in peaches and the plant discates mentemed athere.

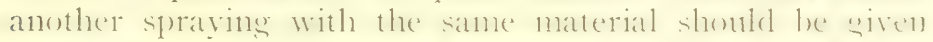

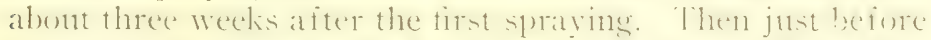

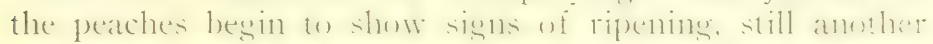
spraving should be wiven, using either the self thesled fince-

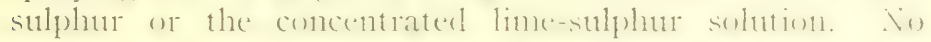
arsenate of lead need txe added ion this spraying as whe curculio or worme is no longer the tromble, and this spmatine is for the purpuse of controlling the hrown rot and scab).

\section{Sprays For Apples and PEars.}

Apples, pears and yuince must also have rather thorough spraying during spring and smmmer if one would grow firstclass fruit. Not only do diseases attack the apple, but the codling moth insect catses these fruts a great real of 
76 How to Succeed (Vith the Home Orchard)

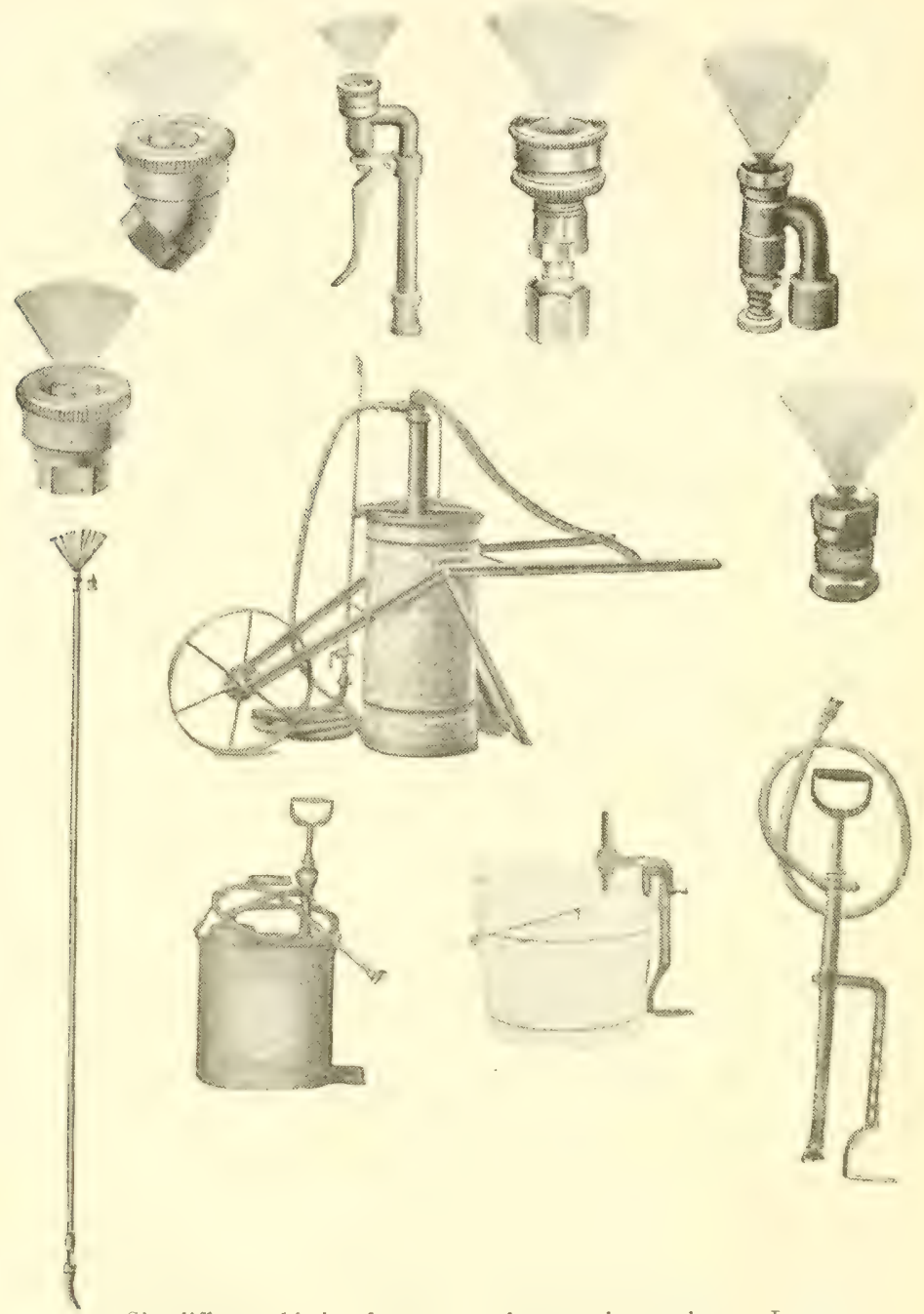

Six different kinds of spray nozzles are shown above. Lower left is an extension rod. Small bucket spray pumps of different types are shown in the center and at the bottom. 
damage. This codling noth is the mature insect which lays the egre that hatches into the worm that is so often found in apples, and it is the early spring and smmmer spravings that must be given in order to control this pest.

When to spray Apples. Pears, Etc. - The first spring spraying wi apples should be siven just ats the last of the bensomm leegin to dall. The bordeatux mixtme or concenttrated line sulphur solution plus 2 pundes of arrenate of

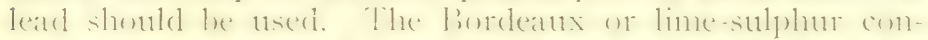
trols the diseases and the arsenate of lead lewks after the codling moth and the kati-ating inseds, whaterer they may be.

When to Ise Bordeaux. For the first pring spraying

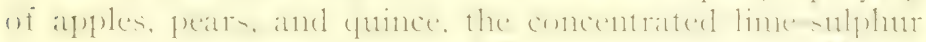

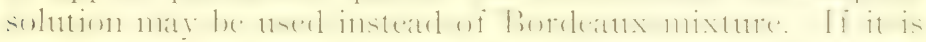

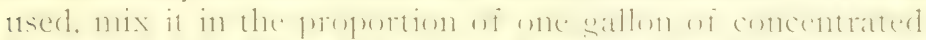

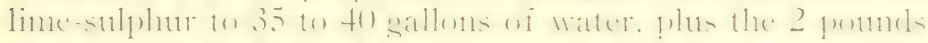

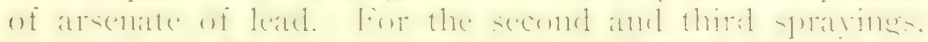

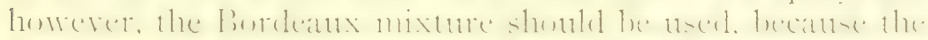

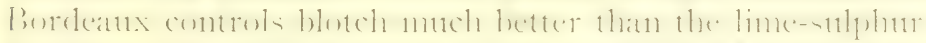

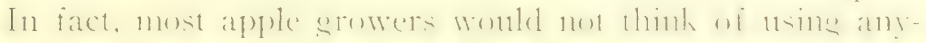

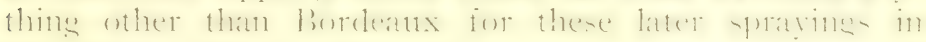
order to control the blotch.

Second and Third Sprayings for Apples. - Dhum thece

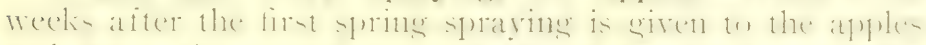

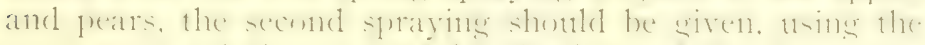

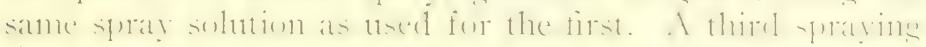

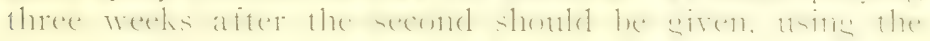
same spray material.

\section{Spring and Summer Sprays For Grapes.}

Start Just Before Blooms (ome out. For erapen the

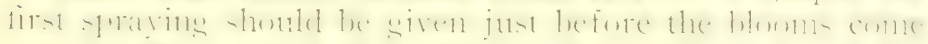

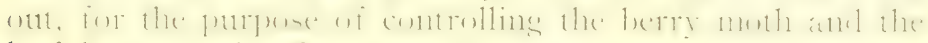
lea i hopper: alse for controlling anthracumes whilew and

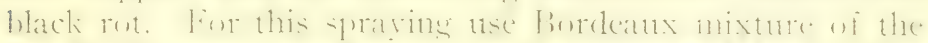

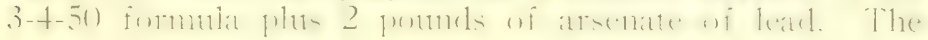


Bordeaux mixture, of course, controls the plant diseases and the arsenate of lead is put on to kill the leaf-eating insects. Then just after the fruit is well set, another spraying with the same material used for the first spraying should be given, for the same insects and plant diseases.

Grapes Require Frequent Spraying.-Approximately two weeks to 18 or 20 days later give the third spraying. For this spraying the same mixture is recommended as for the first and second spraying.

In some instances a fourth, a fifth, and even a sixth spraying may be necessary in order to thoroughly control anthracnose, mildew and black rot of the grape. It is the black rot that causes more trouble than possibly all the other diseases combined on the crape. All are quite familiar with this disease, as very often it attacks the grape to such an extent that a very small portion of them ripens. It is only by thorough spraying, and a sufficient number of times at that, that this trouble can be precented, and it is very well worth while indeed.

On opposite page will be found a spray calendar in condensed form, and from which definite information as to when and with what to spray may be easily secured.

\section{Number Sprayings to Be Given.}

In our spray calendar. we have arranged four sprayings; one during the winter, and three spring and early summer sprayings. Where an orchard is very heavily infested with San Jose scale, a spraying in late fall and one in late winter for this pest will be found advisable. As a rule, however, one of these winter sprayings with limesulphur solution will be found sufficient.

Three Sprayings Necessary. - It is also true that more than three spring and early summer sprayings may be desirable under certain conditions, and it is equally true that under other conditions, two sprayings may suffice. We do not believe, however, that anyone should ever give less than two of the spring or early summer spravings, it mat- 


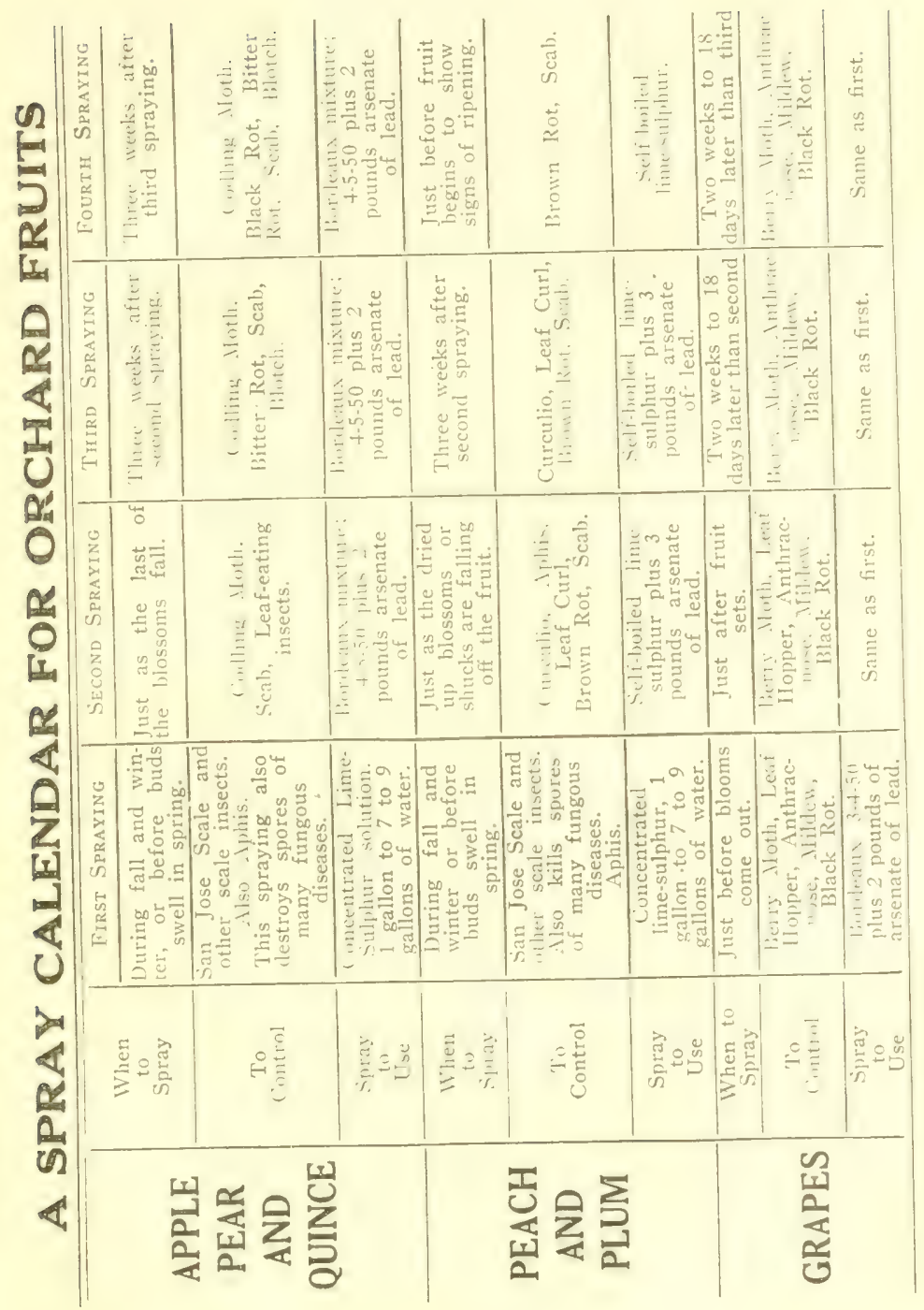


ters not how ideal the conditions may be, or how free from fungons and insect pests the fruit seems to be. We know that spraying is laborioms and costly work, and the owner uf a home orchard does not want to do more spraying than is actually necessary. To be safe we should say, however. that nothing less than three spring or early summer sprayines shomld he given, unless the weather is quite dry and conditions in every respect are ideal to lieep down insect and funeons pests. The later maturing varieties of peaches and apples will naturally need nore spraying than whe early maturing varieties.

Keep Spray Materials on Iland.-It is ufterle difficult to secure the spray mixtures of spraty materials when one watis until the last minute before buying thent. Therefore. the only proper thing to do is to buy these materials comsiderably in adrance. The concentrated lime-sulphure cath le secured from any mumber of firms adrertising in farm papers, and in many instances, from the local drus stores or serel houses. I supply of these should be kept on hand at all times.

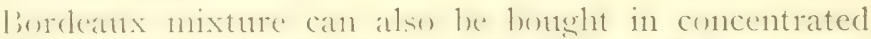
forme, lont those who prefer to do so catn make it at home. birections for making this mixtme are given elsewhere in this book.

Use Spray Mixture Soon Ifter Making.-1he selfhoiled line sulphur wash cammot he buteht in concentrated form and must he made at home, and it should he used in a reasmathe lenesth of time after it is made. as it will not keep for a very great length of time.

fivery persom having a home orcharel shombl. howerer.

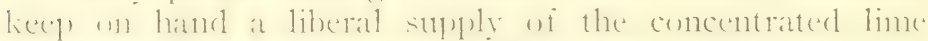

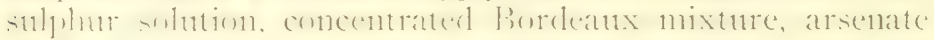

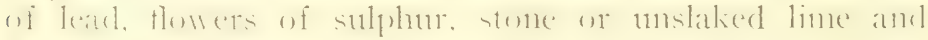

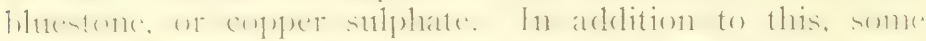

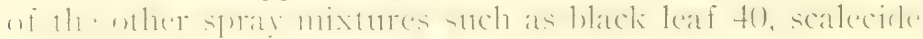
kerosene emulsion, etc., will be found useful. 


\section{CHAPTER XVIII.}

\section{HOW TO MAKE THE SUMMER SPRAY MIXTURES.}

Bordeaus Mixture, (l) all the sply mixtures nsed

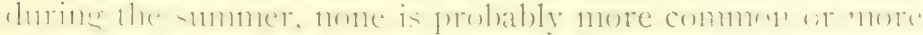

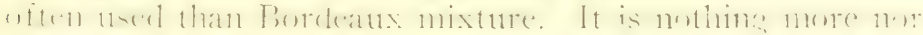

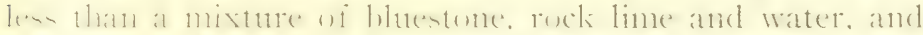

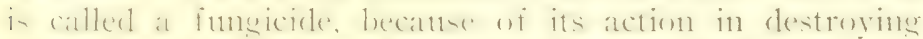

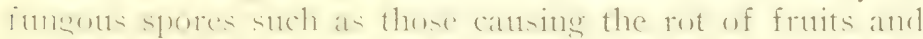
varions other diseases of the frenit and leaves.

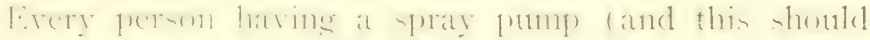

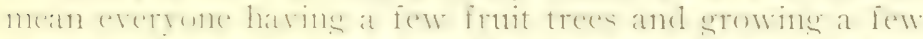

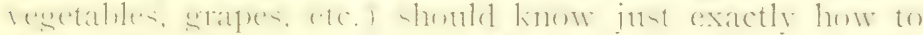

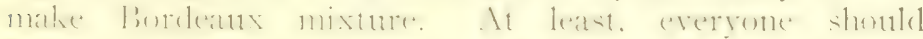
kimo jun what purpuse it serves and how to apply it, because if one does not care to make it, it can

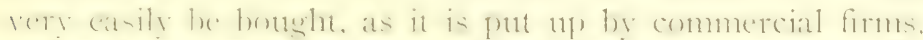

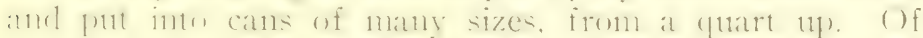
contres, it is futt 11 ) in the concentrated forme and to put it in the right shafe for nse dilute it with water according to instructions which conne with each can or container.

How to Make Bordeaux Mixture. Following is the

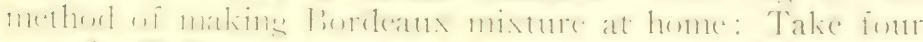

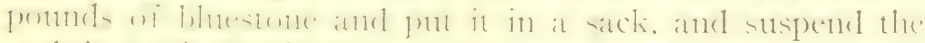

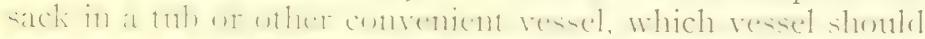

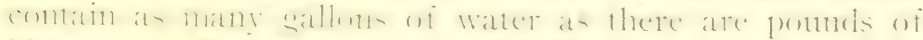

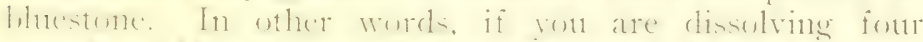

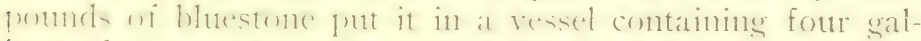

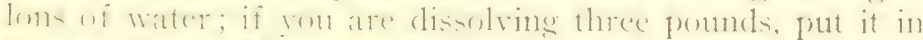

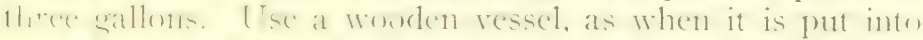
a tin w wher motal resiel. sone chemical action takes plater between the metal and the bluestone.

Suspend Bluestone in Water.-. Suspend this sack conlatining the hinestone in such way that the bluestone is harely covered hy water. Put it in late some afternoon and 
allow it to rentatin in water dorings the night, and it should all be dissolved by morning. If the bluestone is thoown down in the bottonis of the water, it will dissolve very slowly. but hy suspending it, it will dissolve nuch more raprilly. This sives a stock solution that can be liept and wated as

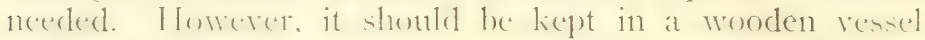
and carefully covered.

To Make 50 Gallons of Bordeaux Mixture. - Vi) when you are reatly to make up 50 gallons of the Pordeatux mixture, talie 5 pounds of ruck line and slate it by ardenes ('monste water to complete the slaking, and make a thin paste. Then pour into the barrel or other container where the spray mixtme is being made. say 25 or 30 gallons of water ; then pour in the solution obtained by slaking the 5 formds of rock lime. Then dip from the stock solution of hluestonte enomgh of the mixtme to get into this barrel four ponnels of hluestone, and if the foresonge directions were fullowed, this would meath the dippong of four gallons of this

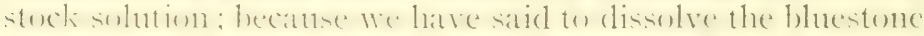
in as matny gallons of water as there are pounde of bluestone. What is neerled then is t ponducls of bluestone. 5 pounds of rock lime. and 5() sallom of Pordeatux mixtme, and when all wi this is in the harrel towether. stir thoroughly and vout are ready for spraying.

\section{Bordeaux Used on Nearly All Frutts.}

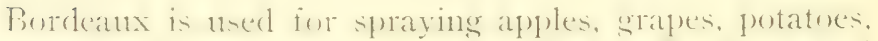
fomatox. and varions other fruits. It is a fungicide and prevents the rot of apples, srapes, blight of potatoes. tomateses, ete. ITherever one is using the Bordeats and wishes to get after some of the insects that eat the fruit. such at the worm in the apple, the bug on the potato, etc.. all that is necessary to make this spray a double-barrel shotwuin is to add to the Bordeaux 21 to 3 pounds of arsenate if lead to each 50 gallons of the mixiture. This gives you snmething that will get loth the diseases and the insects. 
Never Use Slaked I.ime. It mus mol he forsutten that

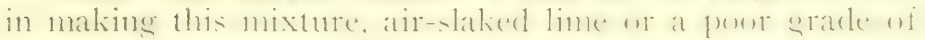

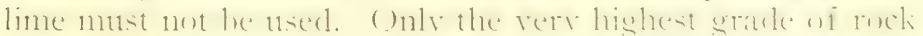
lime that has not heen slaked and is hish-clat in erery respect must be used.

It is alse important to adel a sufficient amoumt of water 10 the line when it is slahing te prevent burnings. Sint wnly

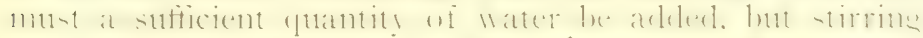

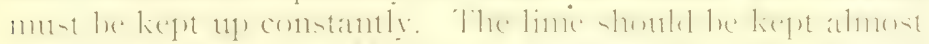

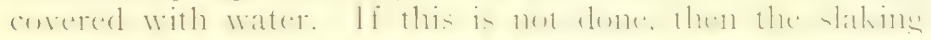

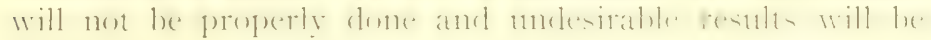
obtained.

Concentrated Solution Retains Strength. Buiture athl ing the arsenate of lead or anything of this kind to the

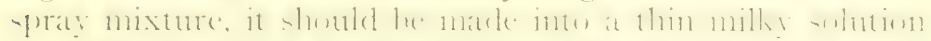

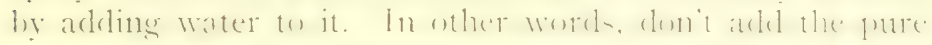
arsenate of lead to the -praty misture. hut dihute it with water into a thin milky solution before it is added.

heep Nixture Covered. Ind herp in mint that line. deaux mixture loses its strength if not used soon after

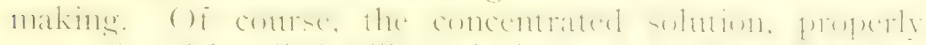

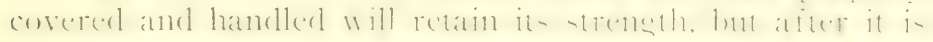

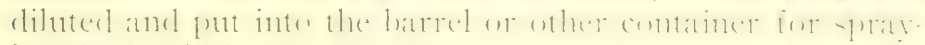
ing, it should be used as soon as possible. 


\section{CHAPTER XIX.}

\section{STORING APPLES FOR WINTER.}

Apples are not so easily liept in storage during the winter in the South as in the North. This may sound strange, but it is a fact. The warmer the weather in the winter, the greater the difficulty in kecping the apples from rotting.

Never Store Apples While Warm.-In the nildde and upper part of the South, however, there is no reason why everyone should not be able to keep well into winter and early spring some of the late winter apples. To do this, henerer, they must be picked at the right time and stored in the right place and in the right way. The important point is to pick then as soon as they are ripe, but do not pick them until they are thoroughly ripe.

Another inmortant point is to see that they are properly cooled before they are carried into the storage place. An ideal way is to pick the apples on a clondy day, or early in the morning before they get warm, and put them in the shade, allowing then to remain there during the day ; then spread them ont in the open during the night and let them get thoroughly cooled. Of course, they should not be put where they will be covered with dew, lut put under at shelter or some place of that lind. Then, early the nexi morning put them inte the storage place. wherever that nay be.

\section{Proper Ventilation Essential.}

Those houses that are equiped with cellars that are well rentilated are all right for storing apples. After carrying them into the cellar or other storage place, leeple it closed during the day so the heat of the day will mot pene trate so much. (Open up at night so ats to permit the com air to enter and then shut the deor the following norning before it gets warm. 
This sante methen can be praticed. surt only with cellarbut with a buxed 111) place under the house, provided, of comrse, it $\mathrm{i}$ - se arranged that it can le well remtilated and is not neatr at place where it will heconne tow warm from

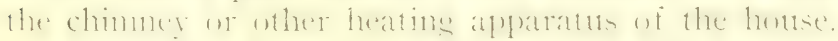

Store Apples When Properly Matured.--lihe proper flime to renember is to gut the atples in storage when they

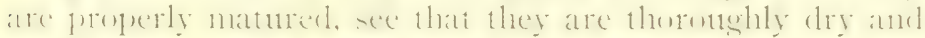
cond whes prut in storatge atul that they are put into such

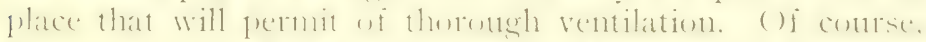

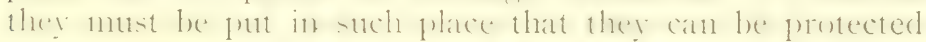
irome serere cold spelis a prevent freczing. but in most sections of the somble there will be fat less damese of the

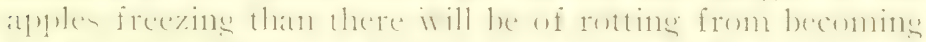

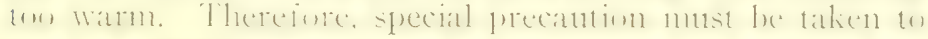
sece te it that thes ix jut in a place where they can be liept

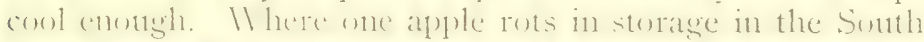

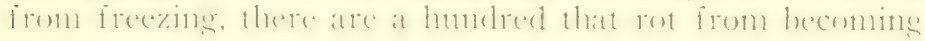
ton warm.

\section{Sitore Apples in Slattei Boxes.}

In sering atsaty atples fer the winter, whether they atre

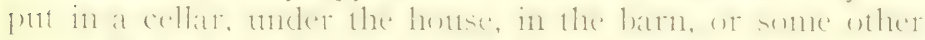

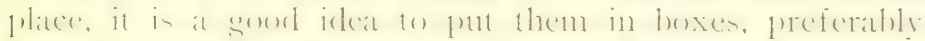
statted luses. These maty hold frome a halt hushel to three

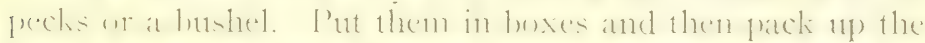

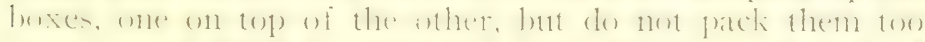

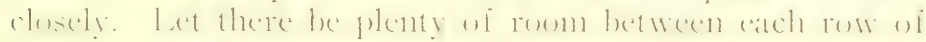
boxes for air to circulate freely.

Where one has only just a few bushels to store, it is all right to put theme in any hind of lox or hasket, but preferithy loxes that are slatted so as to permit the are to circulate at nearly all atrund the apples ats posible.

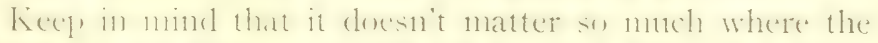
apples are put for sterage if one can put thene in a place where they will not get ton warme and prevent their freezing 
(m) the few nights that are cold enough for them to freeze. These are the important points, and if these simple directions are liept in mind, there is no reason why everyone in the central and upper part of the South should not store some of the late apples for winter use.

\section{Store Only Winter Varieties.}

() f combse, one shoteld wot attemet to store the stmmmer (1) carly fall varieties for winter use. Talie the late maturing varieties and those that leep well, like the IVinesalf, l.moher 'lwig and other varieties of this kind. 'They will lieer) far nore casily than will the early fall varieties.

Remove Covering When All Danger of Freezing IIas passed. - We have seen a few hushels of apples liept sucsuccessiully well into the winter by putting them in a well ventilated barn. When a cold spell came alung some hay, straw or fodeler was thrown over theme taking care, of contse, to remowe the hat or straw as sum as all danger of freezing had passed.

Now, while it is inluertant to store apples where they will not frecoe, we want to again emplnasize the point that it is the heat, or the apples hecominge too warm that one shomld give more attention than anything else. Those whe will put them in properly cooled and keep them coul withont allowing them to freeze, will have ne trouble in keeping them a reasonable leneth of time during the winter. or even into the early spring. 


\section{If You Live in the South}

There is an edition of The Progressive Farmer made to meet your exact needs.

Th. Progrcssive Farmer is not just one paper made to cover the entire South. It is four papers, each called The Progressive Farmer.

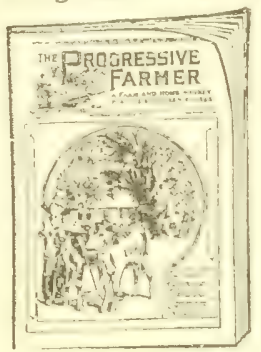

\section{Carolinas-Virginia Edition}

Clarence Poe, Editor in Cliarge

The Progressive Farmer known as our Carolinas-Virginia edition is edited at Raleigh, $N$. $C$, and is made to cover the exact needs of the farmers of Virginia, North Carolina and Sonth Carolina.

\section{Georgia-Alabama Ldition}

\section{C. I. Asserter, Editor in Charge}

Anotler edition is edited in Atlanta, (ieorgia, and IBrmingham, Ala. This is our GeorgiaAlabama edition and male to cover the needs of our reatler friends in (ieorgia, Alabama and lilorida.

\section{Mississippi Valley Edition \\ TAIT IBUtLer, Editor in Charge}

This edition is edited in Memphis, Tennessee. This is known as our Mississippi Valley edition and is made to cover the exact needs of our readers in Tennessee. Mississipni, Arkansas and Lottisianta.

\section{Texas Edition}

\section{(i. Il. Alford, Editor in Charge}

Our 'Texas edition is edited in Dallas, Texas, and made to cover the exact needs of Texas.

In whatever section of the South you may live, there is an edition of The Progressive Farmer made especially for you. The Progressive Farmer is a weekly paper-52 big issues a year-subscription frice $\$ 1$ per year, and sold on a guaranteed basis; that is, if at the end of the year you do not feel that you have had more than your money's worth, you to be the judge, notify us, ani we will gladly refund your money. You have all to gain, and nothing to lose when you subscribe for The Progressive liarmer.

\section{THE PROGRESSIVE FARMER}

\section{EDITORS}

("larence Poe

Tait IButler

II T. IV. IT. II

H. O. Pate

G. H. Alforil

II. C. Iassetter

\section{CONTRIBUTING EDITORS}

('lias. H. Alvord

I). N. Larrow

Eugene Butler

I. F. I ) uggar

A. I.. French

(. I. Ilayden

ii. H. Harrington

s. ('. Hoyle

llary 1. Kapp

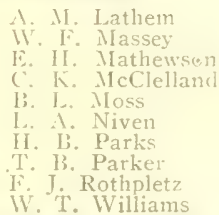

1. MI. Lathem

E. II. Mathewsen

(. K. NcClelland

Ii. I. Moss

L. A. Niven

if. Parks

F. J. Rothpletz

IV. T. Williams

Raleigh, N. C. Atlanta, Ga. Birmingham, Ala. Memphis, Tean. Dallas, Texas 



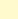








\section{LIBRARY OF CONGRESS ||||||||||||||||||||||||||||||| 000091 ? 154 A}

